\title{
Geochemistry of komatiites and basalts in Archean greenstone belts of Russian Karelia with emphasis on platinum-group elements
}

\author{
Fang-Fang Guo ${ }^{1}$ (D) $\cdot$ Sergei Svetov ${ }^{2} \cdot$ Wolfgang D. Maier $^{3} \cdot$ Eero Hanski $^{1} \cdot$ Sheng-Hong Yang ${ }^{1} \cdot$ Zoya Rybnikova $^{2}$
}

Received: 7 December 2018 / Accepted: 30 June 2019 / Published online: 27 July 2019

(C) The Author(s) 2019

\begin{abstract}
Archean komatiites form an important host rock for Ni-Cu sulfide deposits in the world. In this study, we examined Archean komatiites and komatiitic basalts from four areas in the Vedlozero-Segozero greenstone belt and two areas in the Tikshozero greenstone belt, Russian Karelia, to constrain their Ni-Cu sulfide mineralization potential using chalcophile element geochemistry. The platinum-group element (PGE) concentrations in these Munro-type komatiitic rocks are at a level of other similar Sundersaturated komatiites and komatiitic basalts globally, with Pt and Pd concentrations in the range of 5-20 ppb and Pd/Ir varying from $<10$ (komatiites) to $>15$ (komatiitic basalts and basalts). Generally, the metals of the iridium-group elements (IPGEs; Ir, Ru, Os) show a compatible behavior, decreasing in abundance with decreasing MgO, whereas the metals of the palladium group (PPGEs; Pt, Pd, Rh) exhibit an incompatible behavior. The poor correlation between Ir and $\mathrm{MgO}$ suggests that olivine fractional crystallization is not the main control on the behavior of IPGE. In contrast, Ir, Ru, and Os show positive correlations with $\mathrm{Cr}$, which is consistent with the compatible behavior of IPGEs in chromite or during the co-precipitation of chromite and platinum-group minerals (PGMs). Palladium, $\mathrm{Cu}$, and $\mathrm{Au}$ have been variably mobile during alteration and metamorphism whereas $\mathrm{Pt}$ appears to have been less mobile. Some samples from the Khizovaara area show low $(\mathrm{Pt} / \mathrm{Ti})_{\mathrm{N}}$ ratios, low $\mathrm{Ni}$, and high $\mathrm{La} / \mathrm{Sm}$ and $\mathrm{La} / \mathrm{Nb}$, suggesting localized sulfide saturation in response to crustal contamination. However, the potential of the Russian Karelian greenstone belts for $\mathrm{Ni}-\mathrm{Cu}$ sulfide mineralization is considered relatively low because most samples show neither enrichment nor depletion of chalcophile elements, and the paucity of dynamic lava channel environments, as indicated by the scarcity of olivine-rich adcumulates. In addition, there appears to be a lack of exposed sulfidic sedimentary rocks in the region.
\end{abstract}

Keywords Platinum-group element geochemistry $\cdot$ Komatiite $\cdot$ Greenstone belt $\cdot$ Archean $\cdot$ Russian Karelia

Editorial handling: M. Fiorentini

Electronic supplementary material The online version of this article (https://doi.org/10.1007/s00126-019-00909-0) contains supplementary material, which is available to authorized users.

Fang-Fang Guo guo.fangfang@outlook.com

Sergei Svetov ssvetov@krc.karelia.ru

1 Oulu Mining School, Faculty of Technology, University of Oulu, P.O. Box 3000, FI-90014 Oulu, Finland

2 Institute of Geology, Karelia Research Centre, Russian Academy of Sciences, Petrozavodsk, Karelia, Russia

3 School of Earth and Ocean Sciences, Cardiff University, Cardiff, UK

\section{Introduction}

Komatiites are highly magnesian (>18 wt\% $\mathrm{MgO}$ ) volcanic rocks occurring predominantly in Archean and Paleoproterozoic greenstone belts (e.g., Arndt et al. 2008). Many komatiite-bearing greenstone belts host $\mathrm{Ni}-\mathrm{Cu}$ sulfide deposits (Mudd and Jowitt 2014), and in some cases, they are economically important, notably in the Eastern Goldfields superterrane of the Yilgarn craton and the Abitibi greenstone belt of the Superior craton (Barnes and Fiorentini 2012 and references therein). Komatiites of the Karelian craton in the Fennoscandian Shield have been studied in a considerable detail, both in Russia (e.g., Puchtel et al. 1998, 1999, 2001, 2007; Svetov 2005; Svetov et al. 2001, 2010; Svetov and Smolkin 2003) and Finland (e.g., Jahn et al. 1980; Hanski 1980; Papunen et al. 2009; Hölttä et al. 2012; Maier et al. 2013; Konnunaho et al. 2015), but so far, no significant 
komatiite-hosted Ni-Cu-(PGE) deposits have been discovered, though some small, disseminated sulfide deposits are known to exist in northern and eastern Finland (Konnunaho et al. 2015). A possible exception of significant mineralization is the Paleoproterozoic Sakatti Cu-Ni-PGE deposit, which may be related to magmas of komatiitic affinity (Brownscombe et al. 2015; Makkonen et al. 2017).

Komatiites in eastern Finland, including those in the Tipasjärvi-Kuhmo-Suomussalmi greenstone complex (TKS) and the Ilomantsi and Tulppio greenstone belts, have been dated at ca. 2.75-2.82 Ga (Huhma et al. 2012) and are thought to have been formed in various tectonic settings (Papunen et al. 2009; Hölttä et al. 2012; Maier et al. 2013). Maier et al. (2013) studied the PGE systematics of komatiitic rocks in the greenstone belts in eastern Finland. Based on their relatively evolved composition, the lack of dynamic lava channel environments, and the paucity of PGE-enriched samples in most lavas, it was concluded that, compared with Archean komatiite belts globally, they may have a relatively low $\mathrm{Ni}$ sulfide mineralization potential. In Russian Karelia, Puchtel et al. $(1998,1999,2001,2004)$ determined PGE concentrations of the $2.8 \mathrm{Ga}$ Kostomuksha komatiites, and Puchtel et al. (2007) reported PGE data for 2.9 Ga komatiites in the Volotsk suite. The PGE levels of both these belts seem to be similar to those of the Finnish belts. In the present study, we have determined PGE contents of komatiites in two Archean greenstone belts in Russian Karelia, Vedlozero-Segozero, and Tikshozero, in order to evaluate their prospectivity for $\mathrm{Ni}-\mathrm{Cu}$ sulfide ore deposits.

\section{Geological background}

\section{Geology of the Vedlozero-Segozero greenstone belt}

The Mesoarchean Vedlozero-Segozero greenstone belt is located at the western margin of the Vodlozero terrane (Arestova et al. 2012) in the Karelia craton, Russia (Figs. 1 and 2). It extends for $\sim 300 \mathrm{~km}$ in a N-S direction from Lake Vedlozero to Lake Segozero and is $\sim 50-60 \mathrm{~km}$ wide (Fig. 2). The underlying rocks mostly belong to the tonalite-trondhjemitegranodiorite (TTG) series rocks and have ages of 3.13$3.15 \mathrm{Ga}$ (Arestova et al. 2012, 2015). The greenstone belt is unconformably overlain by Paleoproterozoic Sumian, Sariolian, and Jatulian supracrustal rocks composed of polymictic and quartz conglomerates, quartzites, quartzitic sandstones, and basaltic and basaltic andesite lava flows (Melezhik et al. 2012). All the komatiitic rocks in the Vedlozero-Segozero greenstone belt have undergone seafloor alteration and regional metamorphism, with the latter varying from greenschist to epidote-amphibolite facies, with the pressure ranging from 2 to $4 \mathrm{kbar}$ and the temperature remaining below $540^{\circ} \mathrm{C}$ (Svetov 2005). During these processes, almost all the primary minerals have been replaced by secondary assemblages of actinolitic hornblende, anthophyllite, tremolite, serpentine, chlorite, talc, carbonate, epidote, magnetite, and quartz, but the rocks often contain relics of primary magmatic textures (e.g., ophitic, cumulative, and spinifex).

In the Vedlozero-Segozero greenstone belt, Mesoarchean volcano-sedimentary rocks occur in several areas, including Hautavaara, Koikary, Palaselga, Semch, and Sovdozero, likely representing fragments of an originally larger belt (Svetov et al. 2001; Svetov 2005) (Fig. $2)$. In plane view, these areas form sub-parallel zones separated by gneissose granites (Arestova et al. 2015). We focused our study on four areas (see Fig. 2), which are described in more detail below.

\section{Hautavaara area}

The Hautavaara area is located in the southwestern part of the Vedlozero-Segozero greenstone belt (Fig. 2). It extends in a $\mathrm{N}-\mathrm{S}$ direction for approximately $30 \mathrm{~km}$ and has a maximum width of 10-12 km. Komatiitic to basaltic rocks occur as a sequence varying from 1600 to $1800 \mathrm{~m}$ in its reconstructed thickness and consisting of high-Mg volcanic lava flows, interbedded tuffs, tuffites, and volcano-sedimentary and sedimentary rocks (Fig. 3) (Svetov et al. 2001; Slabunov et al. 2006).

The lowermost member of the sequence with a thickness of $400 \mathrm{~m}$ consists of komatiite lava flows and basalts with interbeds of tuff sandstone, tuffite, chert, and graphitic shale (see Online Resource 1). The middle member reaches a thickness of $700 \mathrm{~m}$ and is composed of massive and pillowed basalts (Online Resource 1) with rare interlayers of tuffitic material. The upper member consists of 350-700 $\mathrm{m}$ of interbedded pillow lavas and massive basalts, with less than $10 \mathrm{~m}$ of tuff and greywacke. Detrital zircon grains from the footwall terrigenous graywackes have yielded an age of $2947 \pm 13$ Ma (SHRIMP-II; Svetov et al. 2006; Fig. 3), defining a maximum age for the komatiitic rocks. Zircon from interlayered felsic volcano-sedimentary rocks in the Hautavaara komatiitebasalt sequence has yielded an age of $2917.2 \pm 8.7 \mathrm{Ma}$ (Svetov et al. 2010; Fig. 3), further constraining the age of the volcanic-sedimentary sequence. The komatiites and basalts from this area are characterized by positive initial $\varepsilon_{\mathrm{Nd}}$ values that vary between +0.4 and +2.4 (Svetov 2005) (Online Resource 2).

\section{Koikary area}

The Koikary area occurs in the central part of the VedlozeroSegozero greenstone belt (Fig. 2). The oldest rocks are exposed in the core of the central anticline, occurring as a lava sequence composed of komatiites and komatiitic basalts, which are overlain by a felsic volcanic-sedimentary formation 
Fig. 1 Regional geological map showing Archean greenstone belts in the Fennoscandian Shield (modified after Maier et al. 2013)

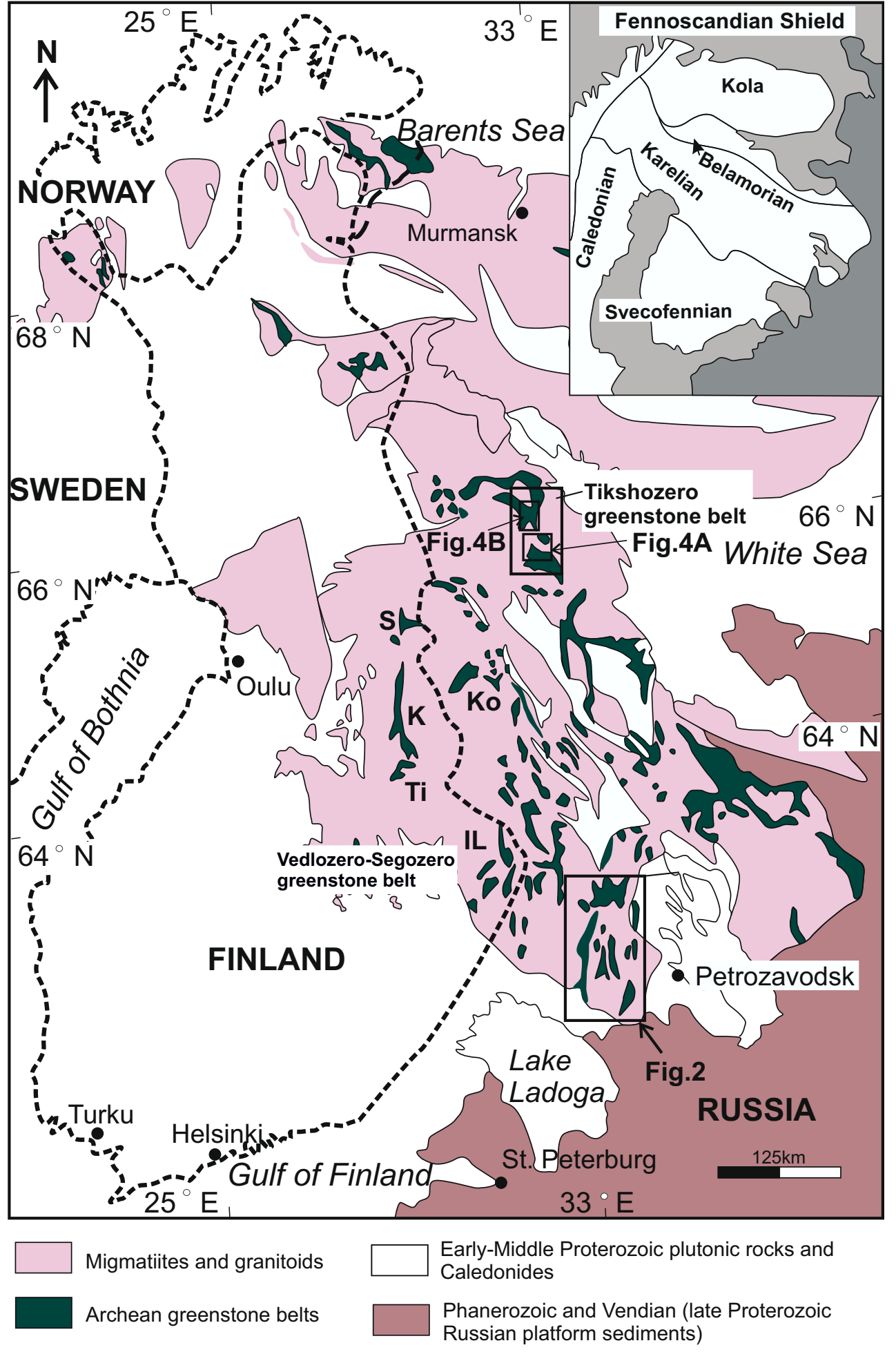

Ti - Tipasjärvi, K - Kuhmo, S- Suomussalmi, IL - Ilomants, Ko - Kostomuksha greenstone belts
(Fig. 3). The lava flows alternate with tuffs and tuffites of komatiitic and basaltic composition. The sequence is 500$550 \mathrm{~m}$ in thickness and is succeeded by an approximately 500-m-thick basaltic unit (Fig. 3). The Koikary volcanic series is dominated by lavas, with pyroclastic and volcano- sedimentary rocks making up approximately $7-10 \%$ of the total volume.

The Koikary komatiites consist of massive lava flows, pillow lavas (Online Resource 1), and occasionally brecciated lava flows containing spinifex-textured lenses. The komatiite- 
Fig. 2 Geological map of the Vedlozero-Segozero greenstone belt in western Russia (modified after Svetov 2005). The study areas shown as squares are (1)

Hautavaara, (2) Koikary, (3)

Palaselga, and (4) Sovdozero

\section{Paleoproterozoic rocks:}

rapakivi granites (1.65-1.54 Ga)

supracrustal rocks (2.50-2.10 Ga)

\section{Neoarchean rocks:}

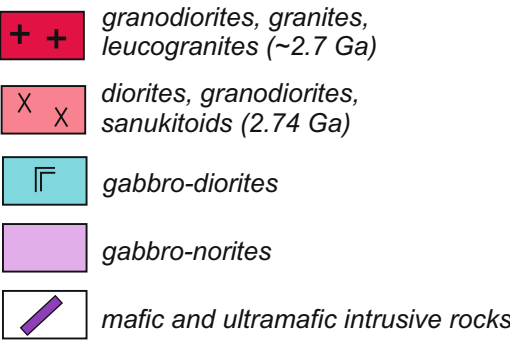

Mesoarchean rocks:

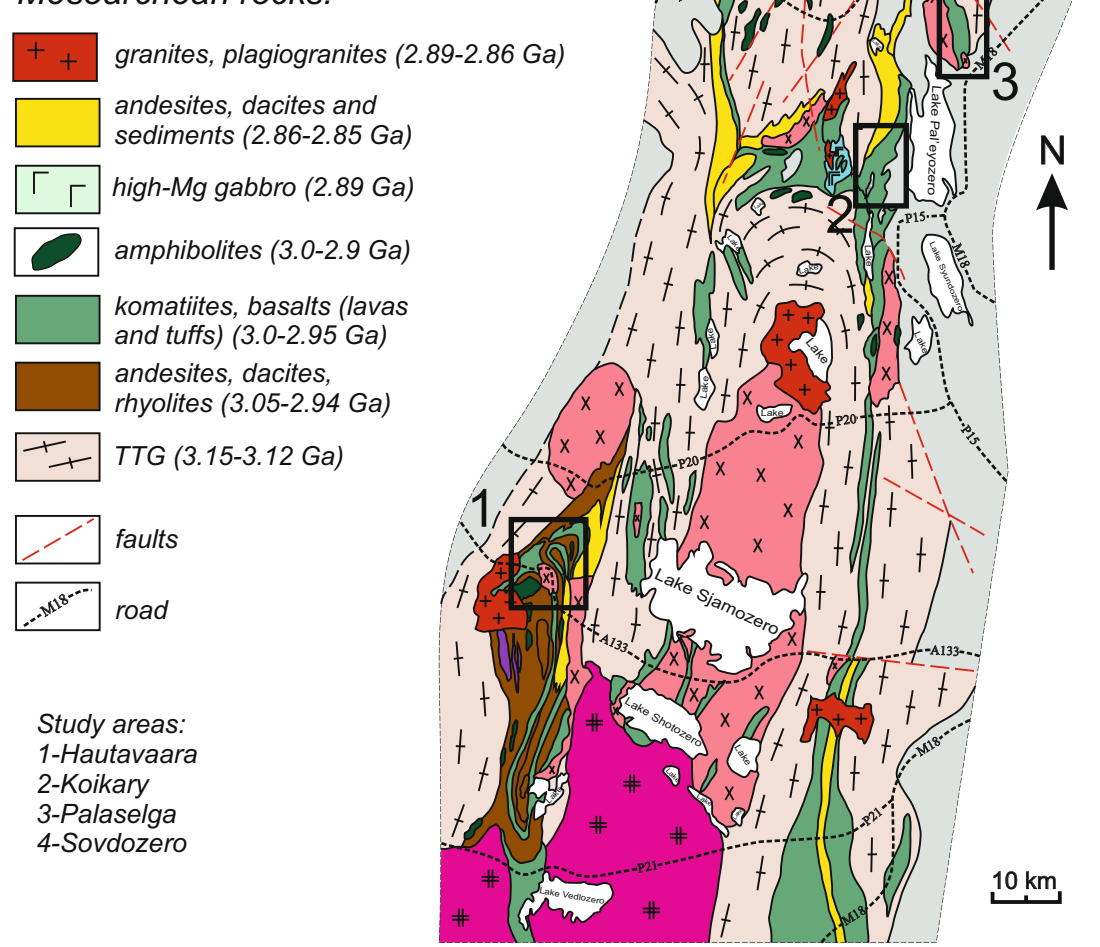

basalt sequence is crosscut by a dacite dike with a U-Pb zircon age of $2935 \pm 20 \mathrm{Ma}$ (Bibikova and Krylov 1983) while the overlying felsic volcanic rocks have yielded a U-Pb zircon age of $2860 \pm 15 \mathrm{Ma}$ (Samsonov et al. 1996). Svetov (2005) reported initial $\varepsilon_{\mathrm{Nd}}$ values from +1.3 to +1.8 for komatiites and basalts in this area (Online Resource 2).

\section{Palaselga area}

The Palaselga area is located approximately $45 \mathrm{~km}$ northeast of Koikary and has a strike length of 14-16 km (NW 340 $\left.{ }^{\circ}\right)$ and a width of 1.5-3.0 km (Fig. 2). Basement rocks (granitegneisses) with an age of $3141 \pm 9.7 \mathrm{Ma}$ are overlain by the Palaselga mafic-ultramafic volcanic sequence, which is dominated by komatiites and komatiitic basalts (Arestova et al. 2012; Fig. 3). This sequence contains three distinct units (Fig. 3), with the 460- to 600-m-thick lowest member containing massive and pillowed lava flows ranging from 10 to $40 \mathrm{~m}$ in thickness. The overlying middle member has a thickness of $\sim 400-450 \mathrm{~m}$ and consists of a series of interbedded komatiite lava flows (Fig. 4c,d) and komatiitic tuff layers varying from 0.5 to $6 \mathrm{~m}$ in thickness. The volume of the pyroclastic rocks at this level does not exceed $4-5 \%$. The upper member is composed of a 800-m-thick series of interbedded pillowed and massive basalts, among which there are separate komatiitic lava flows (Fig. 3). Mafic dikes found within basement tonalities in the Palaselga area are geochemical analogs of komatiitic basalts in the greenstone belt. Arestova et al. 


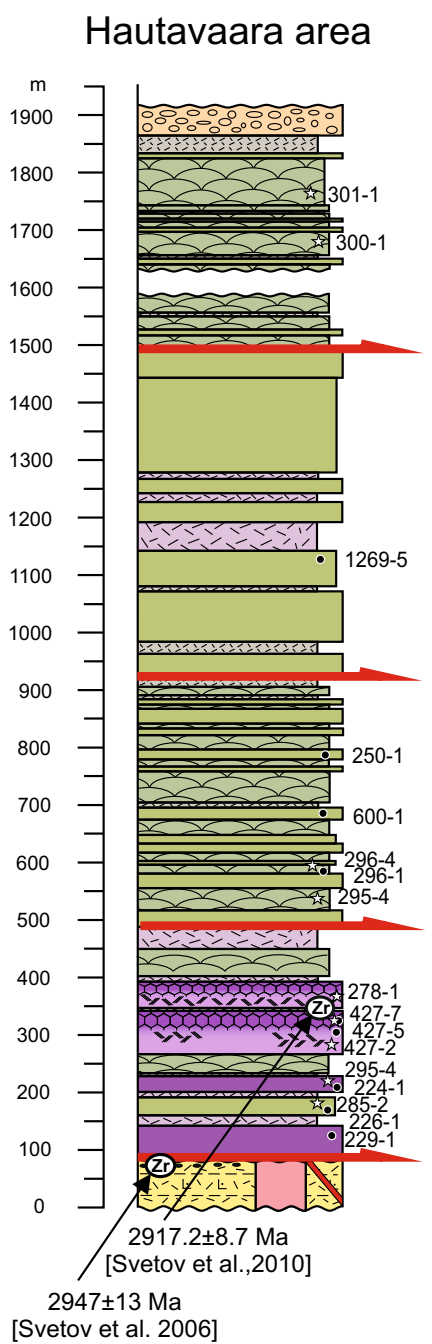

Fig. 3 Simplified stratigraphical sections of komatiite-bearing volcanic successions in the four study areas (Palaselga, Hautavaara, Sovdozero, and Koikary) of the Vedlozero-Segozero greenstone belt

(2012) obtained a U-Pb zircon age of $3020 \pm 14$ for these mafic dikes. Andesitic dikes cutting komatiites in the Palaselga area have been dated by SHRIMP at $2919 \pm$ $14 \mathrm{Ma}$ (Arestova et al. 2012), which is indistinguishable, within error, from the age of the dacite dike at Koikary. Svetov et al. (2001) determined Sm-Nd isotope compositions of komatiites and basalts, yielding initial $\varepsilon_{\mathrm{Nd}}$ values from +0.3 to +1.8 (Online Resource 2).

\section{Sovdozero area}

The Sovdozero area is located in the northwestern part of the Vedlozero-Segozero greenstone belt (Fig. 2), extending for $20 \mathrm{~km}$ in a north-south direction. The Mesoarchean volcano-sedimentary rocks dip to the west at an angle of 65$75^{\circ}$. The komatiite-basaltic sequence is composed of a $150-\mathrm{m}$ thick lower basaltic unit overlain by a 600 -m-thick komatiitic unit, which is capped by $200 \mathrm{~m}$ of basalts in the upper part of the sequence (Fig. 3).

\section{Mesoarchean rocks of Vedlozero-Segozero greenstone belts}
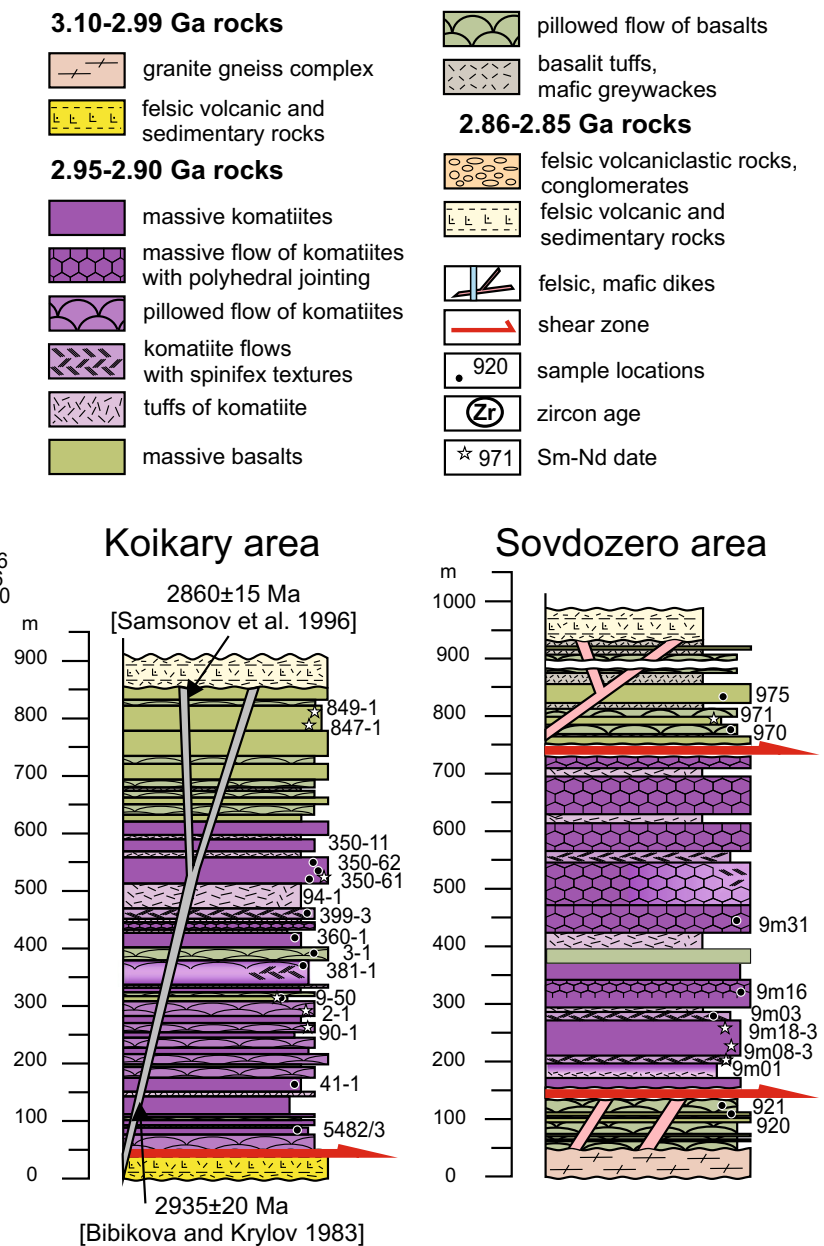

The lower basaltic sequence is formed by alternating flows of massive and pillowed basalts (Online Resource 1). Pyroclastic and volcano-sedimentary rocks constitute no more than $1-2 \%$ of the sequence. Sub-volcanic rocks are represented by sills and dikes of metagabbro-diabase and porphyritic diabase. The lower basaltic unit is cut by numerous dacite dikes and microcline granite veins (Fig. 3). The basaltic rocks are intensely foliated near their contact with the granites (Svetov 2005).

The komatiitic unit consists of a series of lava flows with intercalated beds of tuffaceous material. The volcanic rocks are represented by massive and brecciated komatiitic pillow lavas and lapilli tuffs. The lavas occur as massive, polygonally jointed, brecciated, and spinifex-textured varieties. Autobreccias are developed in the lower and upper parts of massive lava flows, and cumulate zones occur as lenses in autobrecciated komatiitic flows.

The upper basaltic unit exhibits well-preserved lava and tuff textures, and the amount of pyroclastic and volcanosedimentary material increases to $25-30 \%$. The sedimentary 
Fig. 4 Geological map of the Khizovaara (a) and Irinozero (b) areas in the Tikshozero greenstone belt (modified after Shchipansky et al. 2004)

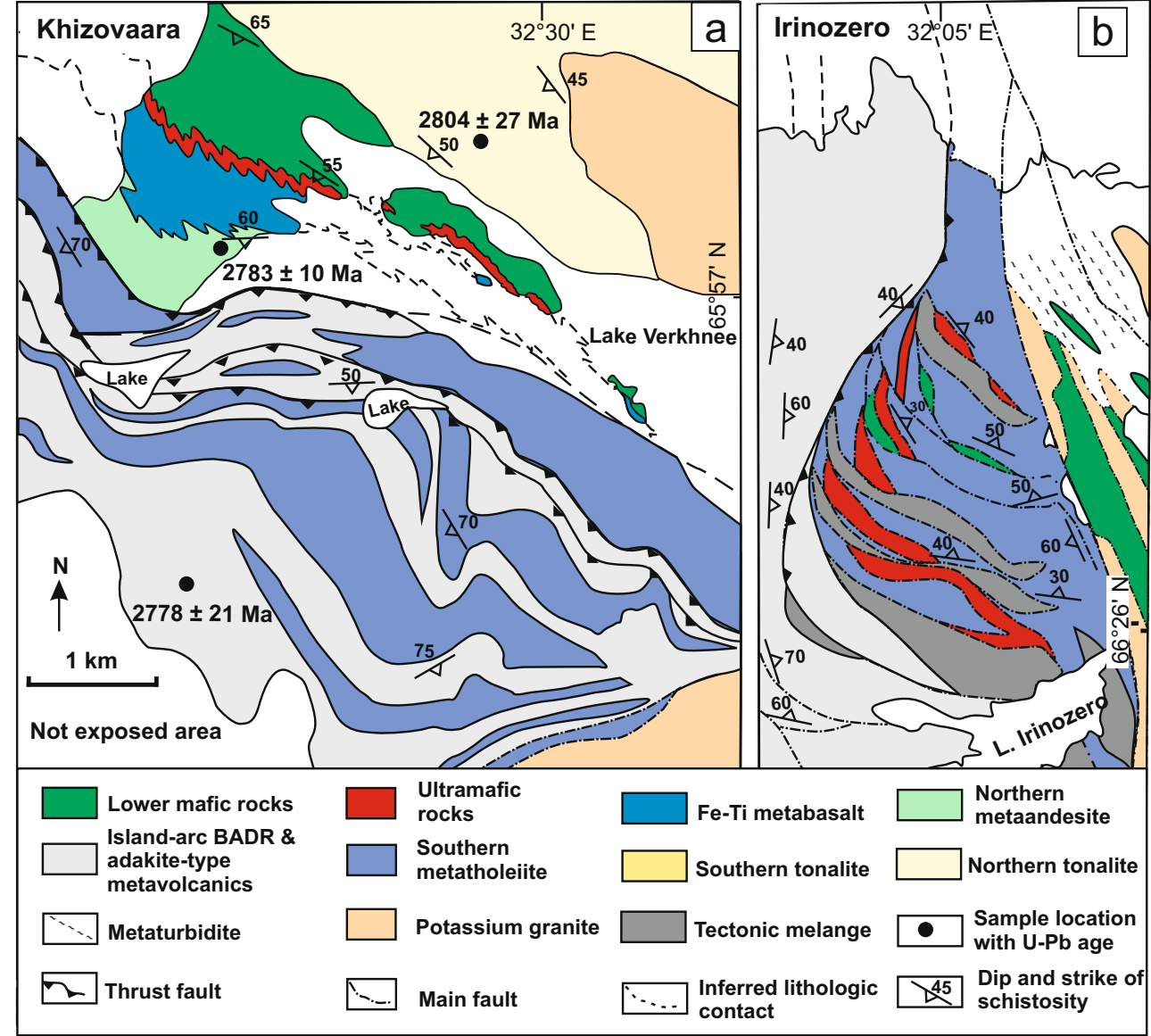

beds are composed of graywacke, basaltic tuff, chert, or banded iron formation (BIF). The komatiites and basalts of the Sovdozero area are also characterized by positive initial $\varepsilon_{\mathrm{Nd}}$ values varying from +1.4 to +2.5 (Svetov 2005) (Online Resource 2$)$.

\section{Geology of the Tikshozero greenstone belt}

The Tikshozero greenstone belt extends for around $300 \mathrm{~km}$ along the boundary between the Karelian granite-greenstone terrain and the Belomorian mobile belt (Fig. 1). It comprises several sub-belts, which are separated from each other by granitoids. All these sub-belts show broadly similar lithologies and structural styles, have undergone amphibolite facie regional metamorphism, with secondary mineral assemblage of serpentine, amphibole, talc, carbonate, and chlorite, and have been interpreted as fragments of an originally single Neoarchean greenstone belt (Kozhevnikov 1992, 2000).

\section{Khizovaara area}

The Khizovaara area is an asymmetrical, structurally complex syncline, which has a southward-plunging axial plane and is made up of volcanic and sedimentary rocks bordered by cutting granitoids (Fig. 4; Kozhevnikov 2000). From the base upwards, the volcano-sedimentary sequence consists of (1) $400 \mathrm{~m}$ of tholeiite with peridotite at the base, (2) $50 \mathrm{~m}$ of komatiite and komatiitic basalts, (3) 400-500 m of Ti-rich ferrobasalts, (4) 300-400 m of andesite, (5) an andesitedacite-rhyolite assemblage of up to $1000 \mathrm{~m}$ in thickness, and (6) an upper tholeiite unit up to $500-600 \mathrm{~m}$ in thickness (Kozhevnikov 2000; Kozhevnikov et al. 2006). The dacitic volcanic rocks in the volcanic-sedimentary formation have yielded an age of $2778 \pm 21 \mathrm{Ma}$ (Fig. 4a), and the whole sequence is cut by a sub-volcanic rhyodacite dated at $2799 \pm$ $67 \mathrm{Ma}$ (Kozhevnikov 1992) and a granite dated at $2804 \pm$ $27 \mathrm{Ma}$ (Bibikova et al. 2003).

\section{Irinozero area}

The Irinozero area is located approximately $100 \mathrm{~km} \mathrm{NW}$ of the Khizovaara area (Figs. 1 and $4 \mathrm{~b}$ ). The lava sequence is overthrust onto a sequence of arc-derived felsic volcanic rocks and siliciclastic turbidites (Shchipansky et al. 2004). The bestpreserved remnant of the sequence occurs along the northern shore of Lake Irinozero (Fig. 4b). It begins with a gabbroic unit with a strong schistosity, which is overlain by a mafic dike unit. A volcanic unit composed of pillowed and massive lava overlies the mafic dike unit. The gabbros, mafic dikes, and 
volcanic rocks show similar geochemical compositions (Shchipansky et al. 2004). A dacite dike from the Irinozero area has been dated at $2782 \pm 9 \mathrm{Ma}$ (Shichipansky et al. 2004).

\section{Sampling and analytical methods}

In order to determine platinum-group element concentrations in mafic and ultramafic volcanic rocks from the studied greenstone belts, we collected 38 samples from the Koikary, Palaselga, Sovdozero, and Hautavaara areas in the VedlozeroSegozero greenstone belt (Fig. 3) and 52 samples from the Irinozero and Khizovaara areas in the Tikshozero greenstone belt. During the sampling, we avoided any outcops which show a strong schistosity or indicate strong alteration, such as talccarbonate alteration. After filtering for any weathering surfaces, veins, and crack fillings, the samples were jaw-crushed and pulverized in a carbon steel mill known to be free of metals other than Fe and Mn. Major element compositions were determined by ICP-OES at Cardiff University and by XRF at the Institute of Geology of the Karelian Research Center of the Russian Academy of Sciences (IG KRC RAS; Petrozavodsk, Russia). Selected trace elements ( $\mathrm{Sc}, \mathrm{V}, \mathrm{Cr}, \mathrm{Co}, \mathrm{Ni}, \mathrm{Cu}, \mathrm{Zn}, \mathrm{Sr}$, $\mathrm{Y}, \mathrm{Zr}, \mathrm{Ba})$ were determined by ICP-OES at Cardiff University. Additional trace elements were determined by ICP-MS at Cardiff University and IG KRC RAS. For ICP-MS trace element analyses, samples were dissolved in a mixture of hydrofluoric and perchloric acids in a Teflon vessel, evaporated, and re-dissolved in nitric acid. To ensure total decomposition of the sample, the solution was filtered and the filter was ashed and fused with $0.2 \mathrm{~g}$ of lithium metaborate and $0.02 \mathrm{~g}$ sodium metaborate, followed by dissolution of the fused bead in nitric acid and in combination with the filtrate. This method digests most refractory minerals and provides acceptable precision for all elements. The error is less than $2 \%$ for elements at concentrations above $0.5 \mathrm{wt} \%, 3 \%$ at concentrations above $30 \mathrm{ppm}$, and $5 \%$ at concentrations below $30 \mathrm{ppm}$. Three reference materials, JB1a, NIM-N, and NIM-P, were used to monitor the reproducibility of both major and trace elements (McDonald and Viljoen 2006).

Platinum-group elements and Au were determined by ICPMS after Ni-sulfide fire assay and tellurium co-precipitation in the analytical laboratory of the University of Quebec at Chicoutimi (Laboratoire d'Analyses Géochimiques de l'UQAC) (for analytical details, see Savard et al. 2010). The weight of the analyzed samples varied from 3 to $6 \mathrm{~g}$. For $\mathrm{Pd}$ and $\mathrm{Au}$ analyses, the precision was considerably lower than that for Ir, $\mathrm{Ru}, \mathrm{Rh}$, and $\mathrm{Pt}$ due to relatively high $\mathrm{Pd}$ and $\mathrm{Au}$ contents in the blank $(0.17 \pm 0.26 \mathrm{ppb}$ for $\mathrm{Pd}, 0.4$ $\pm 0.3 \mathrm{ppb}$ for $\mathrm{Au})$. Two reference material standards, OKUM (komatiite) and WMS-1a (Wellgreen massive sulfide), were used to monitor the reproducibility (Savard et al. 2010) (Table 1).

\section{Analytical results}

\section{Major and trace elements}

Average major and trace element compositions of komatiites and komatiite basalts of different areas from the VedlozeroSegozero and Tikshozero greenstone belts are listed in Table 2 (original full data are available in Online Resource 3). For the purpose of plotting the data in diagrams, all major element compositions were recalculated to $100 \%$ on a volatile-free basis. Our samples have normalized $\mathrm{MgO}$ contents between 7.0 and $37.1 \mathrm{wt} \%$, representing basalts, komatiitic basalts, and komatiites. The komatiitic samples from different areas show average $\mathrm{Al}_{2} \mathrm{O}_{3} / \mathrm{TiO}_{2}$ ratios of 21.1 (Irinozero), 21.1 (Khizovaara), 18.7 (Koikary), 21.0 (Hautavaara), 21.3 (Sovdozero), and 26.3 (Palaselga). In Fig. 5, most of them plot in the field of Al-undepleted (or Munro-type) komatiites, the most common variety of Mesoarchean and Neoarchean komatiites globally (Nesbitt et al. 1979).

The samples from both greenstone belts have a negative correlation between $\mathrm{MgO}$ and $\mathrm{SiO}_{2}, \mathrm{TiO}_{2}, \mathrm{Al}_{2} \mathrm{O}_{3}$, and $\mathrm{CaO}$ (Fig. 9a-d), forming continuous trends from komatiites to komatiitic basalts and basalts. This suggests that these rocks form a differentiation series related to olivine accumulation and fractionation. Samples from both greenstone belts also show a well-defined positive correlation on the $\mathrm{Ni}$ vs. $\mathrm{MgO}$ diagram (Fig. 6e), consistent with olivine-controlled trends. Notably, a few samples from the Khizovaara area and one sample from the Irinozero area have slightly higher Ni contents plotting above the main trend (Fig. 6e).

In sulfide-undersaturated silicate melts, $\mathrm{Cu}$ abundances should increase during fractional crystallization of olivine and other silicate minerals, as $\mathrm{Cu}$ is incompatible in these minerals. However, the $\mathrm{Cu}$ contents of our samples show a significant scatter when plotted against $\mathrm{MgO}$ (Fig. 6f). Most of the samples have a $\mathrm{Cu}$ content of less than $200 \mathrm{ppm}$, with three exceptions that have higher $\mathrm{Cu}$ contents between 284 and $491 \mathrm{ppm}$. The scatter is likely due to secondary mobility caused by alteration and/or metasomatism during regional metamorphism.

On the $\mathrm{Cr}$ vs. $\mathrm{MgO}$ plot (Fig. 6g), our komatiitic samples with $\mathrm{MgO}$ greater than $25 \mathrm{wt} \%$ display two different trends: a negative correlation indicating mixing of olivine with chromite-undersaturated komatiitic liquid and a positive linear trend reflecting co-accumulation of olivine and chromite.

$\mathrm{The} \mathrm{Zr}$ contents in the samples from the Segozero-Veldozero and Tikshozero greenstone belts plot at the lower end of a global database (Fig. 6h), indicating a relatively lower degree of crustal contamination compared with other greenstone belts globally. Chondrite-normalized rare earth element (REE) patterns and primitive mantle-normalized trace element patterns of the komatiites and komatiitic basalts from the VedlozeroSegozero and Tikshozero greenstone belts are shown in Fig. 7. In these diagrams, the samples from the studied areas are 
Table 1 Reproducibility of PGE standards

\begin{tabular}{lccccccc}
\hline & $\mathrm{Ru}(\mathrm{ppb})$ & $\mathrm{Rh}(\mathrm{ppb})$ & $\mathrm{Pd}(\mathrm{ppb})$ & $\mathrm{Os}(\mathrm{ppb})$ & $\operatorname{Ir}(\mathrm{ppb})$ & $\mathrm{Pt}(\mathrm{ppb})$ & $\mathrm{Au}(\mathrm{ppb})$ \\
\hline OKUM-1 & 4.25 & 1.49 & 11.79 & 0.9 & 1.03 & 12.3 & 1.46 \\
OKUM-2 & 4.09 & 1.52 & 11.87 & 0.8 & 1.14 & 12.05 & 0.92 \\
OKUM-3 & 4.36 & 1.58 & 12.08 & 0.56 & 1.06 & 12.26 & 0.95 \\
Okum reference values & $4.25 \pm 0.30$ & $1.40 \pm 0.13$ & $11.7 \pm 0.5$ & $0.98 \pm 0.34$ & $0.99 \pm 0.07$ & $11.0 \pm 0.6$ & $1.41 \pm 0.57$ \\
WMS-1a & 140.45 & 264.96 & 1530.71 & 138.97 & 324.62 & 1944.31 & 144.16 \\
WMS1-a & 163.04 & 267.51 & 1542.08 & 174.53 & 342.33 & 1978.81 & 318.57 \\
WMS-1a reference values & 145 & 222 & 1450 & 150 & 322 & 1910 \\
\hline
\end{tabular}

divided into two groups, with one representing komatiites $(\mathrm{MgO}>18 \mathrm{wt} \%)$ and the other komatiitic basalts (MgO 10 $18 \mathrm{wt} \%)$ and basalts ( $\mathrm{MgO} 5-10 \mathrm{wt} \%)$. Most samples from the Vedlozero-Segozero greenstone belt have flat or slightly fractionated patterns with enriched LREE contents and weak negative $\mathrm{Nb}$-Ta anomalies (Fig. 8).

Samples from the Khizovaara area can be divided into two sub-groups. One group is slightly depleted in LREE (Fig. 7), while the other shows a relative LREE enrichment and significant negative Nb-Ta anomalies (Fig. 7). Samples from the Irinozero area show similar REE patterns to those of the LREE-depleted groups of the Khizovaara area, with most samples having weak Nb-Ta anomalies (Fig. 7).

In Fig. 8, primitive mantle-normalized $(\mathrm{Nb} / \mathrm{La})_{\mathrm{N}}$ ratio is plotted against $(\mathrm{Nb} / \mathrm{Th})_{\mathrm{N}}$ ratio. Samples from both the Vedlozero-Segozero and Tikshozero greenstone belts display positive correlations, with most samples showing lower $(\mathrm{Nb} /$ $\mathrm{La})_{\mathrm{N}}$ and $(\mathrm{Nb} / \mathrm{Th})_{\mathrm{N}}$ ratios than primitive mantle (PM, McDonough and Sun 1995), towards average upper continental crust composition (Rudnick and Gao 2003).

\section{Platinum-group elements}

The concentrations of PGEs and Au of the analyzed komatiite and komatiite basalt samples are presented in Table 2. The PGE contents of most of the komatiite samples are in the global range of Al-undepleted komatiites, with up to $15.1 \mathrm{ppb} \mathrm{Pt}$, 20.9 ppb Pd, 8.99 ppb Ir, 6.35 ppb Ru, 6.71 ppb Os, and $27.7 \mathrm{ppb}$ Au. Three samples from the Vedlozero-Segozero belt show a higher Pd concentration than the others, but their $\mathrm{Pt}$ contents are in the range of the other samples.

Iridium and $\mathrm{Ru}$ show generally positive correlations with $\mathrm{MgO}$ with a few exceptions (Fig. 9). Platinum, $\mathrm{Pd}$, and $\mathrm{Au}$ contents generally increase with falling $\mathrm{MgO}$ contents, but there is a sharp decrease when the $\mathrm{MgO}$ content falls below $10 \mathrm{wt} \%$. Rhodium shows a slight increase with decreasing $\mathrm{MgO}$. Due to the different compatibility of IPGE (iridium group, Ir, Ru, Os) and PPGE (palladium group, Pt, Pd, Rh), the $\mathrm{Pd} / \mathrm{Ir}$ ratio broadly increases with decreasing $\mathrm{MgO}$. On the primitive mantle-normalized chalcophile element diagrams, basalts and komatiitic basalts display more fractionated trends than komatiites and olivine cumulates (Fig. 10).

On the Pd vs. Pt diagram, most samples plot on a linear trend, excluding three samples from the Sovdozero area and one sample from the Khizovaara area, which plot above this trend (Fig. 11a). On the Rh vs. Pd plot, these four samples also stand out from the main linear trend (Fig. 11b). However, all the samples form a linear trend on the Rh vs. Pt diagram (Fig. 11c). This is evidence for Pd having been slightly mobile during post-magmatic processes.

\section{Discussion}

\section{Crystal fractionation}

Platinum-group elements have high partition coefficients with regard to sulfide and silicate melts (e.g., Stone et al. 1990; Fleet et al. 1991, 1999) and have therefore been widely used to evaluate whether or not mafic-ultramafic magmas have equilibrated with sulfides (e.g., Maier et al. 2003; Barnes and Fiorentini 2008; Fiorentini et al. 2010). However, the behavior of IPGE during magma fractionation is not fully understood. It has been proposed in many past studies that IPGEs are compatible in chromite (Puchtel and Humayun 2001; Stone and Crocket 2003; Brenan et al. 2003). In contrast, based on whole-rock geochemistry, Barnes and Fiorentini (2008) found no correlation between $\mathrm{Cr}$ and $\mathrm{Ir}$ and suggest that the IPGEs are not compatible in chromite but are hosted by alloys. Righter et al. (2004) obtained high partition coefficients of IPGE with regard to chromite, with the values varying from 5 to 22,000, which are higher than the partition coefficients of $\sim 20$ determined experimentally (Capobianco and Drake 1990). These experimental data suggest that chromite may be an important phase controlling IPGE. In our data set, most of the samples show positive correlations between $\mathrm{Ir}, \mathrm{Ru}$, and $\mathrm{Cr}$ (Fig. 12), which could potentially be explained by the compatibility of IPGE in chromite. This is consistent with in situ LA-ICP-MS analyses that indicate, in komatiites, that the IPGE may be partly incorporated into the chromite lattice (Pagé et al. 2012; Locmelis et al. 2013, 2018; 


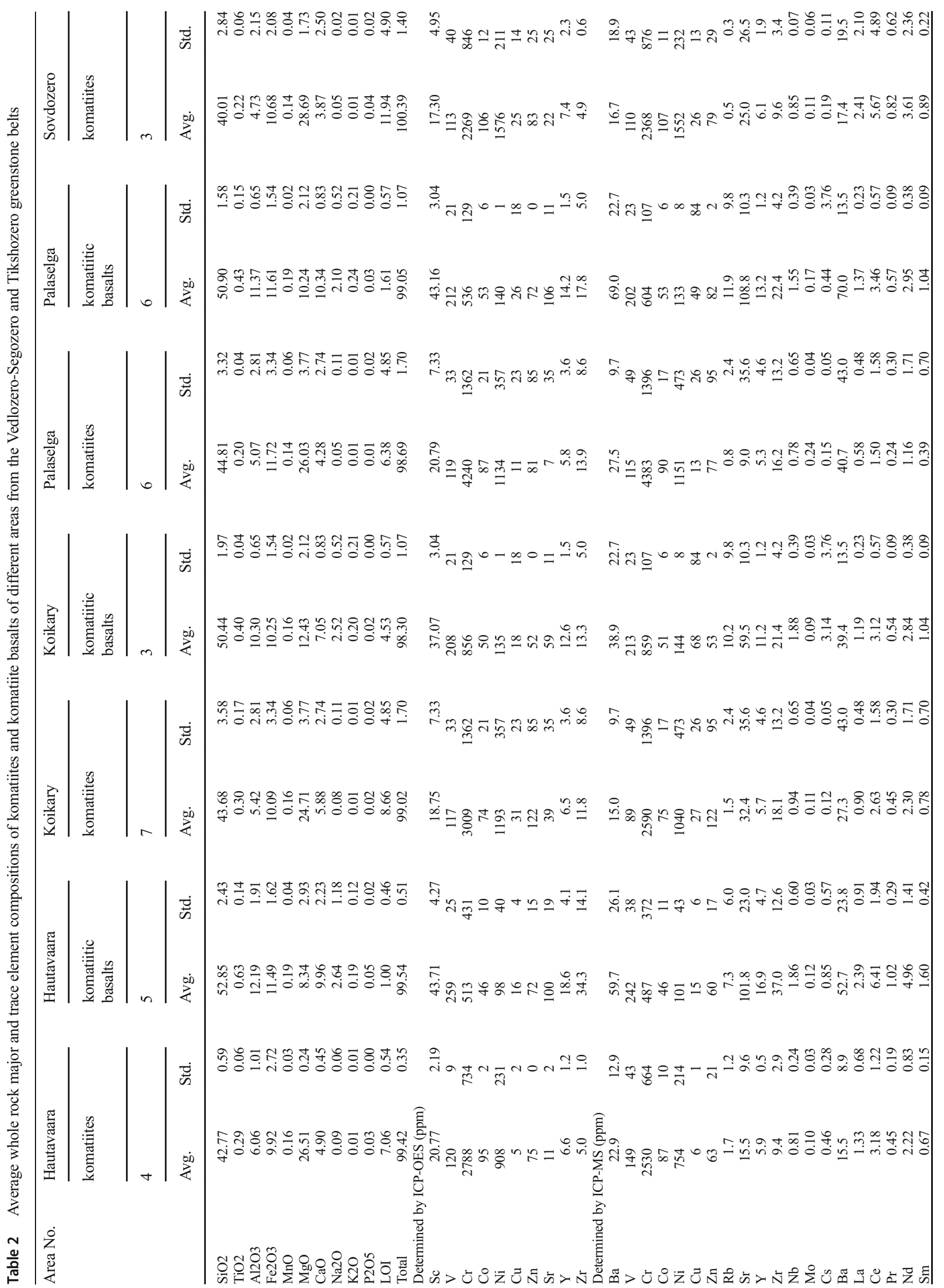




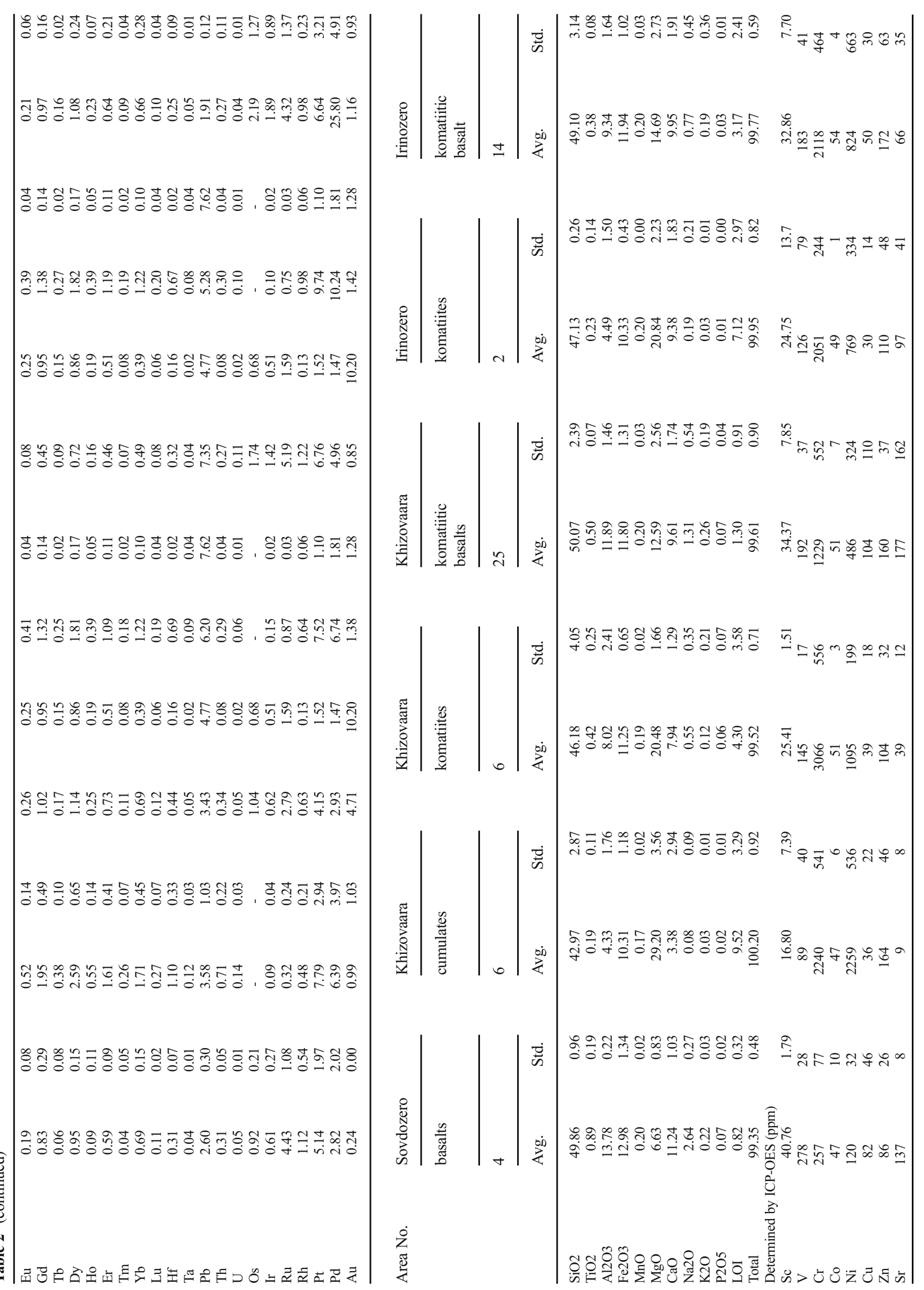




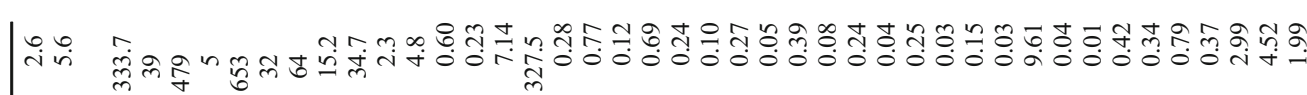

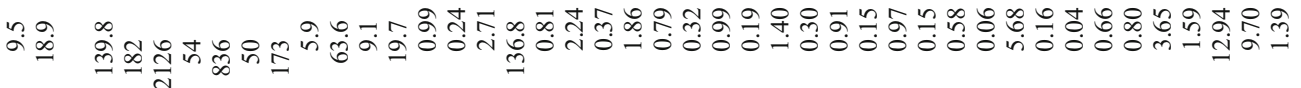

개

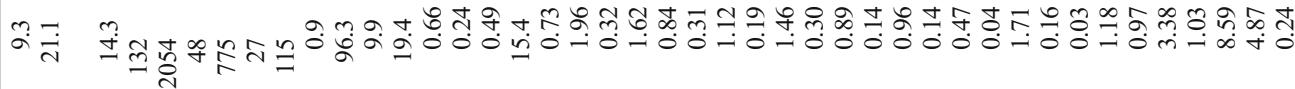

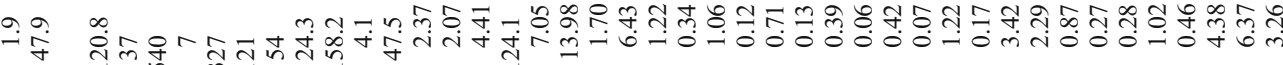

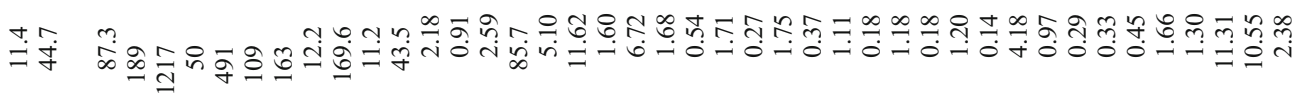

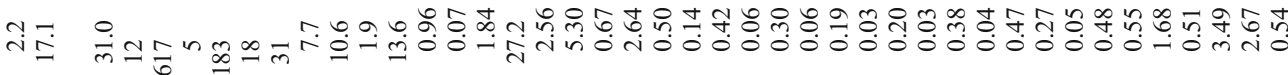

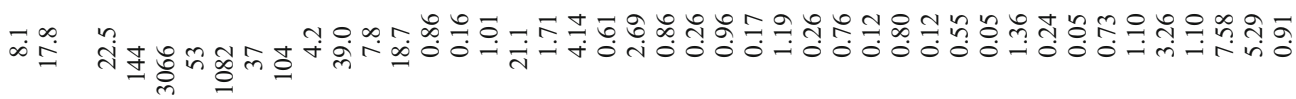

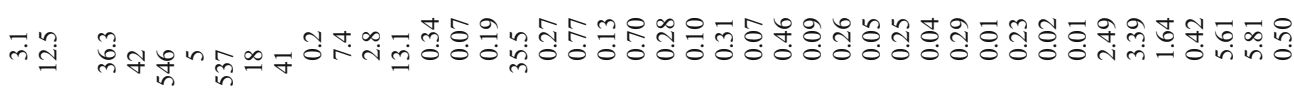

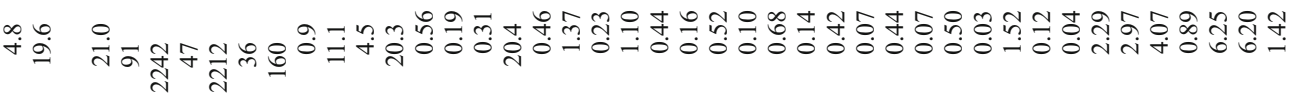

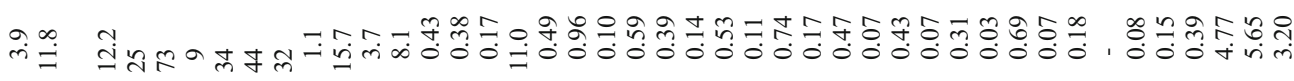

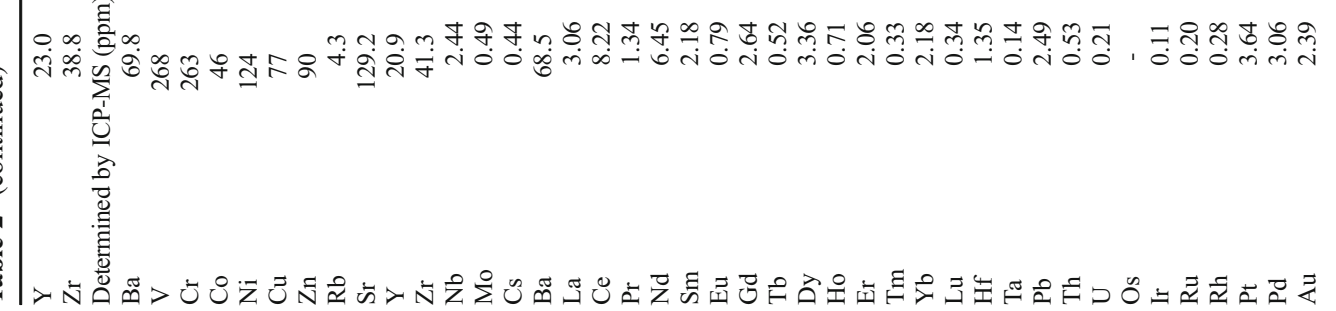




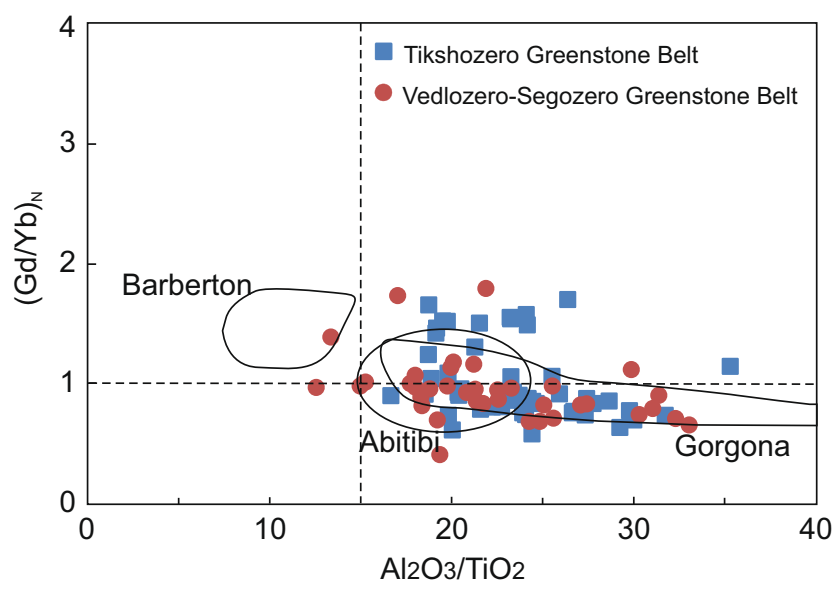

Fig. $5 \mathrm{Gd} / \mathrm{Yb}$ vs. $\mathrm{Al}_{2} \mathrm{O}_{3} / \mathrm{TiO}_{2}$ diagram for komatiites from the VedlozeroSegozero and Tikshozero greenstone belts. Also shown are fields for the Barberton komatiite type (Al-depleted) and the Munro and Gorgona komatiite types (Al-undepleted) after Arndt et al. (2008). Note that most of the komatiite samples from the Vedlozero-Segozero and Tikshozero greenstone belts belong to the Al-undepleted type

Park et al. 2017), though IPGE is rather low in chromites of basalt (Ballhaus and Sylvester 2000; Godel et al. 2007; Godel and Barnes 2008). A few of our samples with moderate $\mathrm{Cr}$ contents but rather high Ir contents (up to $8 \mathrm{ppb}$ ) plot away from the main trend, indicating that IPGE may not only be controlled by chromite but also by IPGE-rich platinum-group minerals or alloys (e.g., laurite, Fig. 12; Barnes and Fiorentini 2008; Maier et al. 2015). The elevated Ir level could not be explained by the presence of sulfide, because these samples do not show unusual high Pt and Pd contents (about 2 ppb). The komatiites in eastern Finland show similar patterns, with most samples plotting on a positive correlation trend between IGE and $\mathrm{Cr}$ and a few samples plotting above the trend (Maier et al. 2013).

Some authors have proposed that Ir is hosted in olivine (Brenan et al. 2005). However, based on empirical data, Puchtel et al. (2004) evaluated that the olivine/melt partition coefficients for IPGE in komatiitic systems fall in the range of 0.2 to 1.0 , indicating a moderately incompatible nature of IPGE. On the Ir vs. $\mathrm{MgO}$ diagram (Fig. 9), our samples show a weak positive correlation. Considering that $\mathrm{MgO}$ tends to be mobile during alteration and metamorphism, the data do not provide clear indications for or against the olivine control for Ir. A similar pattern has also been observed in komatiites from the Yilgarn craton (Barnes and Fiorentini 2008) and Finnish greenstone belts (Maier et al. 2013).

\section{Evaluation of ore potential}

\section{Interaction between magma and crustal rocks}

Komatiites host some of the world's most important Ni sulfide deposits, notably in the Yilgarn craton (Mudd and Jowitt 2014). Smaller Ni deposits also occur in komatiites of the Zimbabwe craton and the Abitibi greenstone belt in Canada (Barnes and Fiorentini 2012 and references therein). Nickel sulfide mineralization has been found in different types of komatiites (Al-depleted and Al-undepleted komatiites) and in different tectonic settings (e.g., Arndt et al. 2008). Crustal contamination is an important factor in the formation of komatiite-hosted sulfide deposits, by increasing the $\mathrm{S}$ content of the magma through addition of external $\mathrm{S}$ and by decreasing the sulfur solubility in magma through addition of $\mathrm{Si}$ and other crustal components (Lightfoot and Hawkesworth 1997; Lesher and Keays 2002; Arndt 2008; Lesher and Barnes 2009; Barnes and Fiorentini 2008, 2012; Barnes et al. 2011). In the Vedlozero-Segozero greenstone belt, most samples show flat LREE or slightly LREE-enriched patterns with weak negative $\mathrm{Nb}$-Ta anomalies on primitive mantle normalized multi-element plots (Fig. 7). In the Tikshozero greenstone belt, a group of samples from the Khizovaara area shows a LREE-enriched chemical signature, which is accompanied by negative $\mathrm{Nb}-\mathrm{Ta}$ anomalies (Fig. 7). These features could be explained by crustal contamination. This is supported by the observed positive correlation between $(\mathrm{Nb} / \mathrm{Th})_{\mathrm{N}}$ and $(\mathrm{Nb} / \mathrm{La})_{\mathrm{N}}$ and the relatively low values of these two ratios in most samples compared with the primitive mantle value, as continental crust has low $(\mathrm{Nb} / \mathrm{Th})_{\mathrm{N}}$ and $(\mathrm{Nb} / \mathrm{La})_{\mathrm{N}}$ ratios (Puchtel et al. 1998).

As komatiites are normally generally sulfur-undersaturated during eruption, contamination with S-bearing crustal rocks is considered an important, if not essential factor in the formation of komatiitic Ni-sulfide deposits (e.g., Keays and Lightfoot 2010; Barnes and Fiorentini 2012). In the Agnew-Wiluna greenstone belt of Western Australia, Ni-Cu sulfide-mineralized komatiites are spatially associated with abundant volcanic massive sulfide (VMS) deposits, which have potentially provided external sulfur to the komatiitic magma, thereby triggering sulfide melt saturation and the formation of Ni sulfide mineralization (Fiorentini et al. 2012). The Alexo, Texmont, and Hart sulfide deposits in the Abitibi greenstone belt have also been regarded as results of sulfide immiscibility triggered by assimilation of sulfidic sedimentary rocks (Lahaye et al. 2001). In the Karelia craton, Konnunaho et al. (2013) presented multiple sulfur isotope evidence that the komatiites related to the Vaara $\mathrm{Ni}$ deposit in the Suomussalmi greenstone belt have assimilated external sulfur. Archean sulfide-bearing BIF have been reported to be present in the Ilomantsi and Kostomuksha greenstone belts (Sorjonen-Ward et al. and Luukkonen 2005; Kuleshevich and Gor'kovets 2008), which could potentially have provided external sulfur to the komatiites to form sulfide deposits. In the Sovdozero area of the Vedlozero-Segozero greenstone belt, BIF occurs above the komatiite rocks in the upper part of the volcanic sedimentary sequence and was thus formed later than the major komatiitic magmatism. This is consistent with the slightly older age of the komatiites in the Vedlozero-Segozero belt compared with that of the Ilomantsi and Kostomuksha belt komatiites. There are no reports of the occurrence of BIF in the 

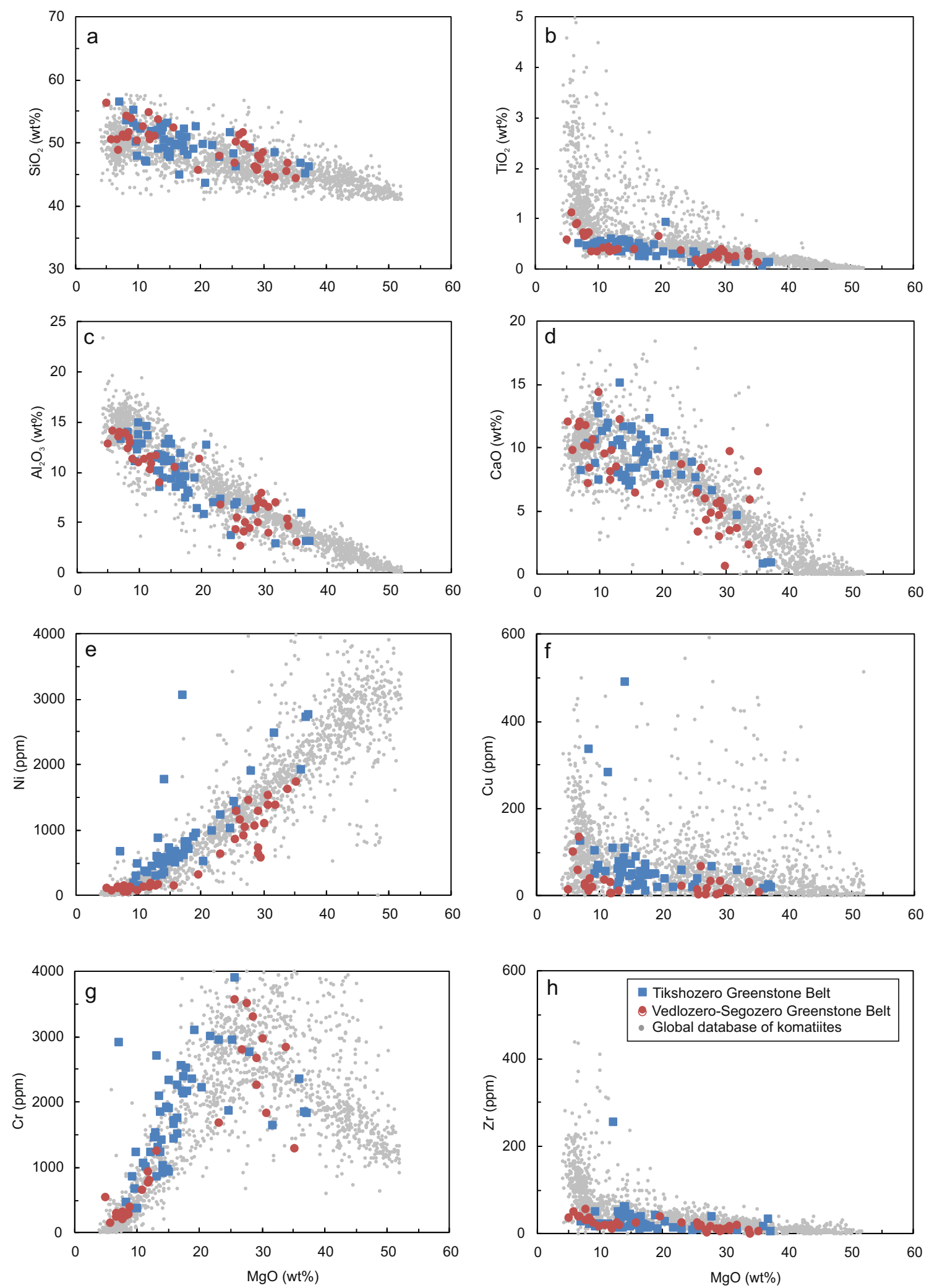

Fig. 6 Variation of $\mathrm{TiO}_{2}, \mathrm{Al}_{2} \mathrm{O}_{3}, \mathrm{CaO}, \mathrm{Ni}, \mathrm{Cu}, \mathrm{Zr}$, and $\mathrm{Cr}$ as a function of $\mathrm{MgO}$ in komatiites from the Vedlozero-Segozero and Tikshozero greenstone belts. For comparison, analytical data from a global komatiite database are also shown (Barnes and Fiorentini 2012)

Tikshozero greenstone belt. Accordingly, in the VedlozeroSegozero and Tikshozero greenstone belts, the absence of sulfide-rich sedimentary rocks could imply a relatively low prospectivity for $\mathrm{Ni}-\mathrm{Cu}$ sulfide mineralization. 
Fig. 7 Primitive mantlenormalized trace element diagrams for komatiites in the Vedlozero-Segozero and Tikshozero greenstone belts. Normalization values are from McDonough and Sun (1995)
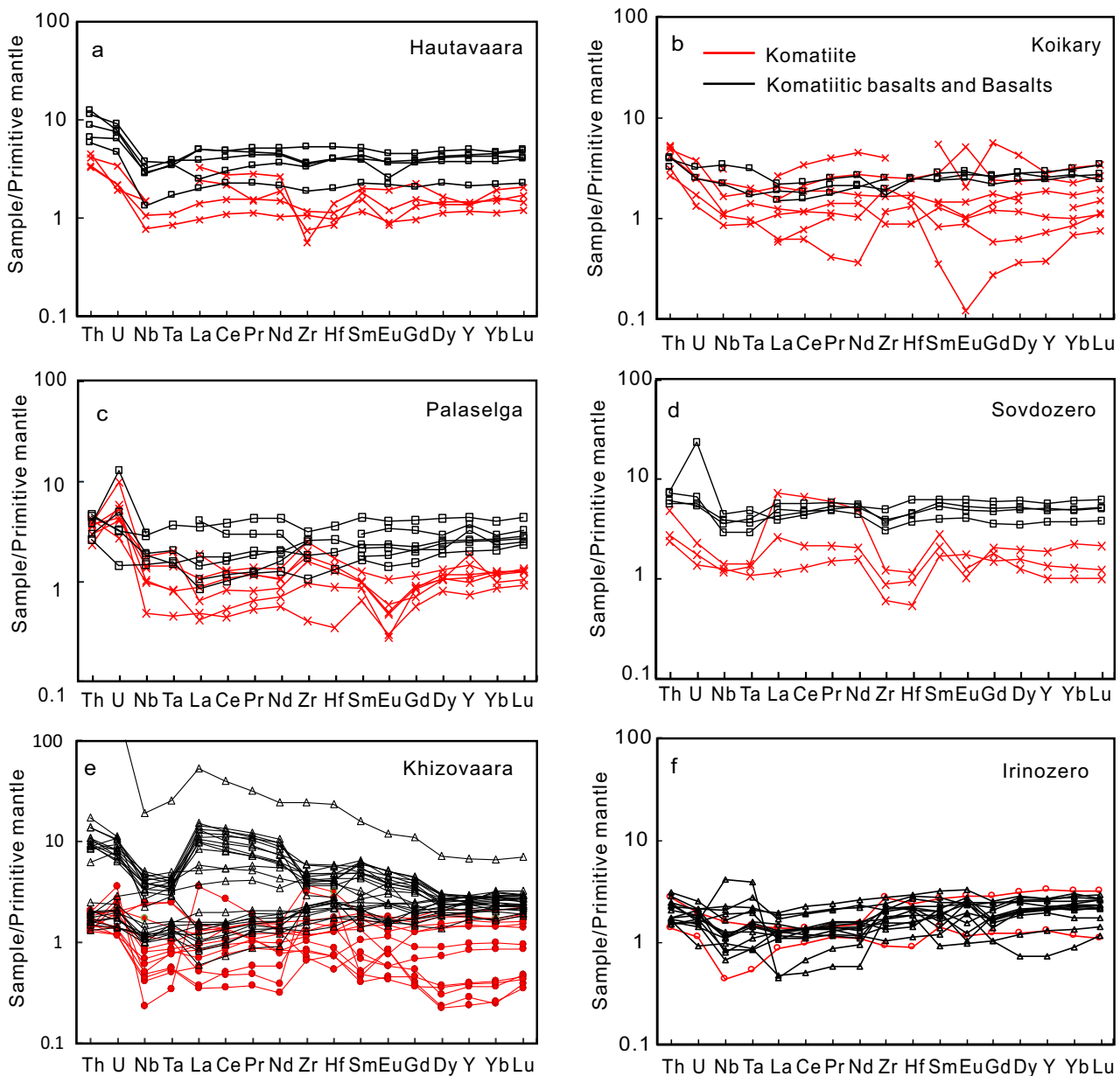

\section{Metal depletion or enrichment related to sulfide segregation}

Traditionally, chalcophile element depletion in maficultramafic lavas has been used in the evaluation of the $\mathrm{Ni}$ prospectivity of greenstone belts (Lesher and Keays 2002; Lesher and Barnes 2009; Barnes and Fiorentini 2012), as it is a useful indicator of sulfide saturation. Fiorentini et al. (2010) presented a systematic comparison of the PGE abundances in sulfide-free samples from well-mineralized and barren komatiites and found that the well-mineralized komatiites show a large scatter in the PGE abundances with both enrichment and depletion, whereas the barren komatiites show neither PGE enrichment nor depletion.

On the Pd vs. MgO diagram (Fig. 9), the samples of this study show a considerable scatter, with three samples from the Vedlozero-Segozero belt plotting above the rest of the data. These samples have high $\mathrm{MgO}$ contents (27-31 wt\%) and likely represent komatiitic cumulates. It is unlikely that the
Fig. $8(\mathrm{Nb} / \mathrm{Th})_{\mathrm{N}}$ vs. $(\mathrm{Nb} / \mathrm{La})_{\mathrm{N}}$ value for the samples from Vedlozero-Segozero and Tikshozero greenstone belts. For comparison, the value of the upper continental crust (UCC) and primitive mantle $(\mathrm{PM})$ are plotted in the diagram (Pucthel et al. 1998)
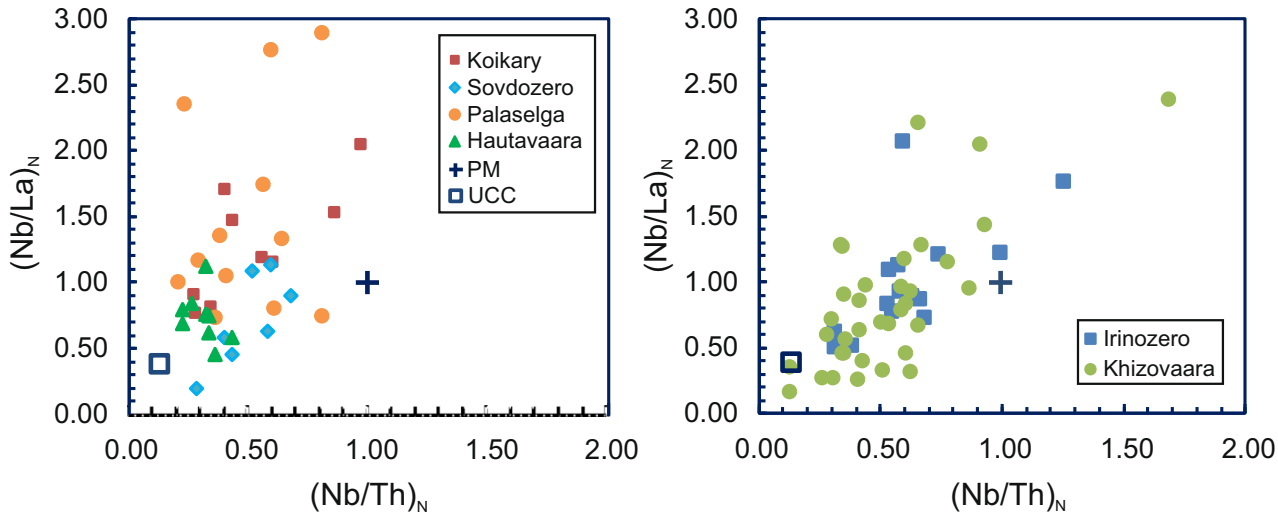

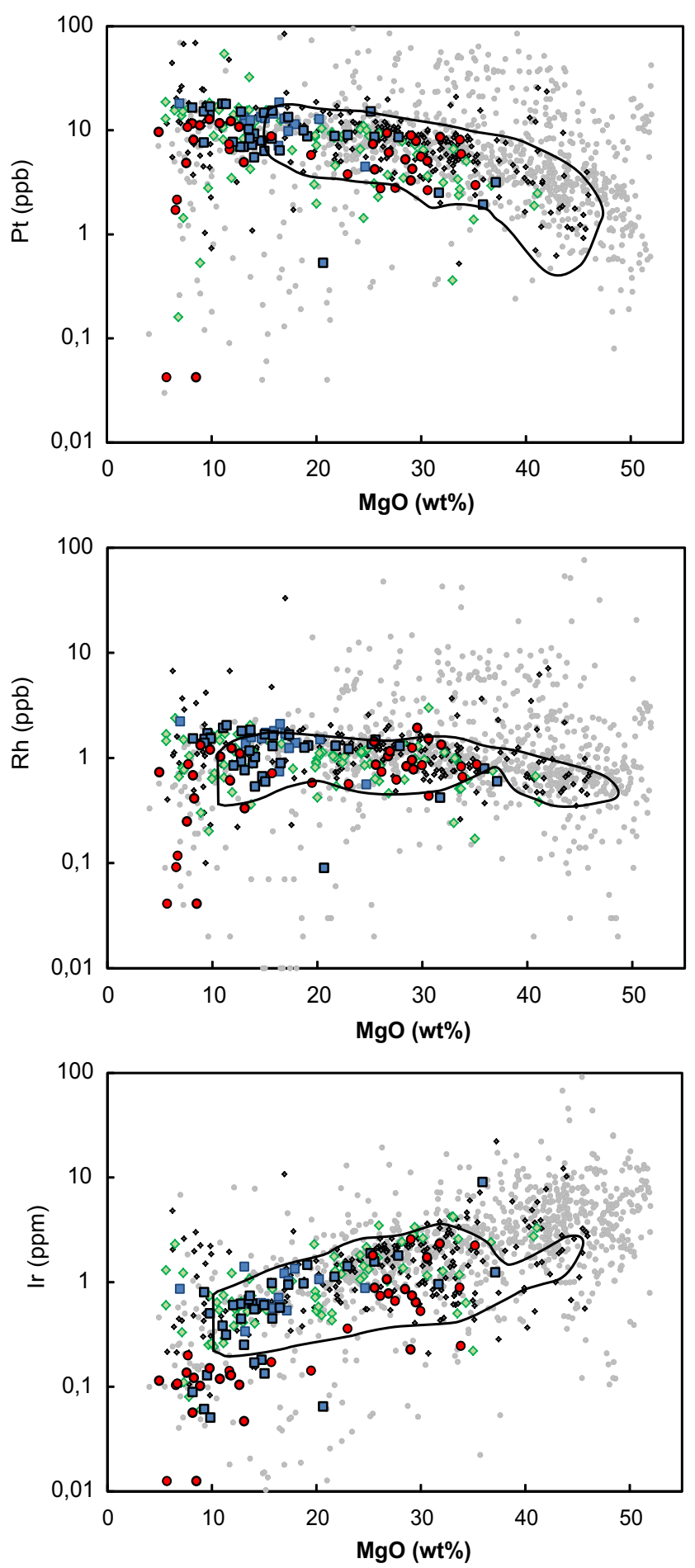

Fig. 9 Plots of platinum-group elements vs. $\mathrm{MgO}$ for komatiites in the Vedlozero-Segozero and Tikshozero greenstone belts. For comparison, analytical data from a global komatiite database are also shown, with

elevated Pd content reflects the presence of cumulus sulfide, as this should also have resulted in elevated Pt contents. Hence, the high Pd concentration in these samples probably results from the mobility of Pd during alteration and/or metasomatism during metamorphism. This is consistent with the
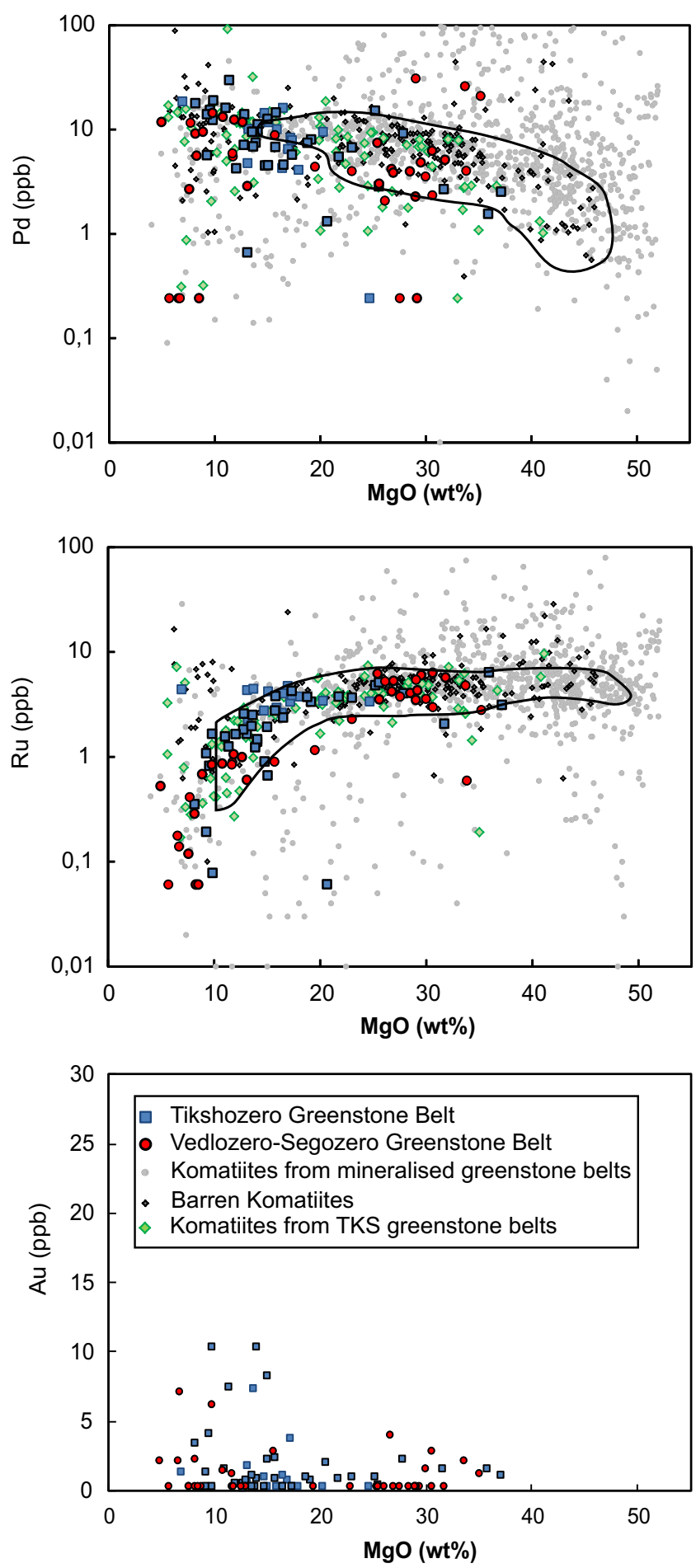

the outline representing the field of komatiites from unmineralized greenstone terrane (Barnes and Fiorentini 2012)

relatively poor correlation between $\mathrm{Pt}$ and $\mathrm{Pd}$ (Fig. 11), whereas Pt and Rh show a good correlation (Fig. 9). However, most of the samples follow a negative trend on the Pt and Pd vs. $\mathrm{MgO}$ diagrams with only a few komatiites and basalts being depleted in Pt and Pd (Fig. 9). In Fig. 9, komatiite samples 
Fig. 10 Primitive mantlenormalized chalcophile element diagram for komatiites in the Vedlozero-Segozero and Tikshozero greenstone belts. Normalization values are from McDonough and Sun (1995)
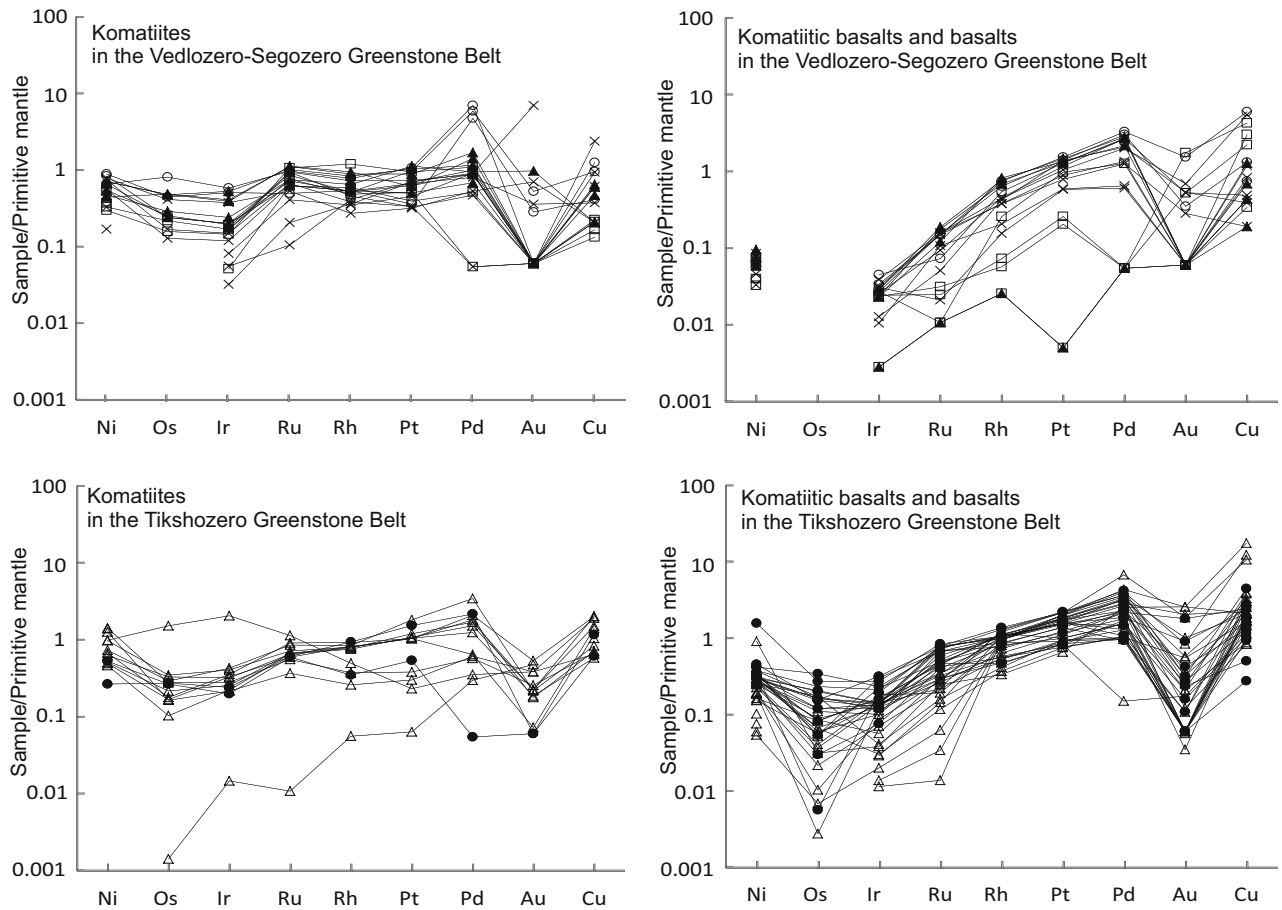

from both Russian Karelia and Finland plot within the global field of barren komatiites, being clearly different from wellmineralized komatiites. Consequently, these data indicate that the komatiites in Russian Karelia did not undergo extensive sulfide liquid saturation, which is not a good indication for the presence of Ni sulfide mineralization.
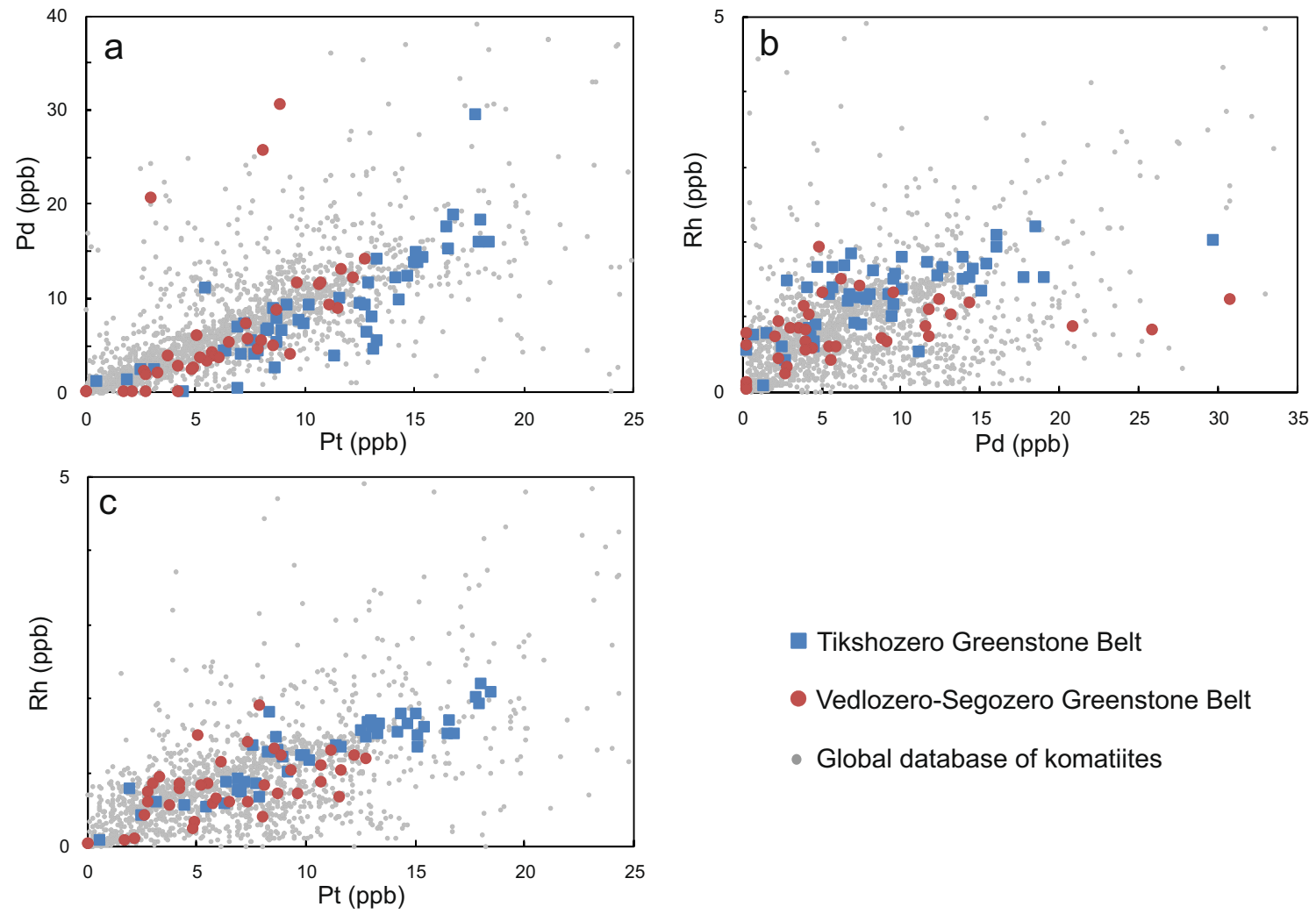

- Tikshozero Greenstone Belt

- Vedlozero-Segozero Greenstone Belt

- Global database of komatiites

Fig. $11 \mathrm{Pt}, \mathrm{Pd}$, and Rh contents in komatiites in the Vedlozero-Segozero and Tikshozero greenstone belts compared with analytical data from a global komatiite database (Barnes and Fiorentini 2012) 

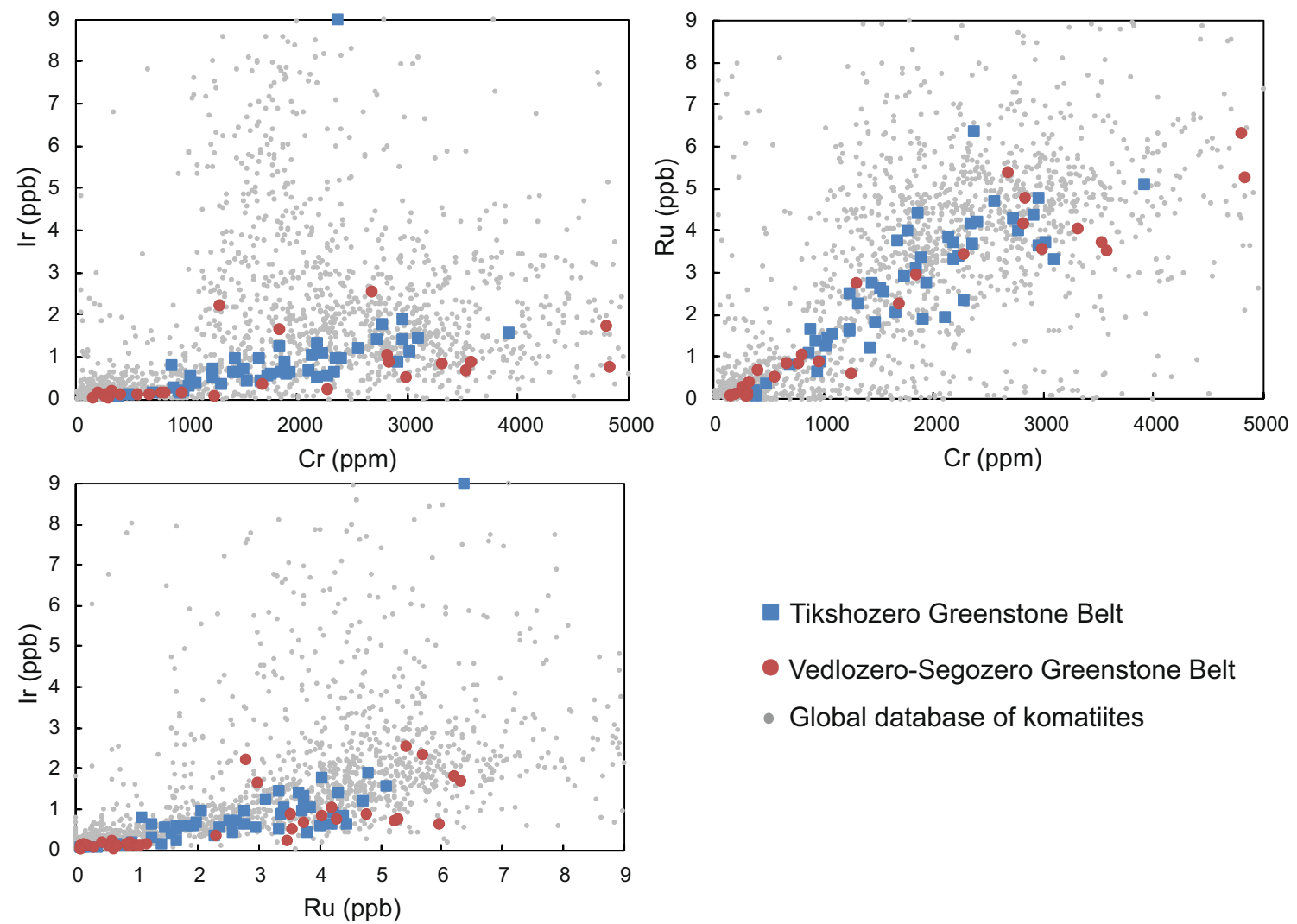

Fig. 12 Plots of Ir and Ru vs. Cr and Ir vs. Ru for komatiites in the Vedlozero-Segozero and Tikshozero greenstone belts. For comparison, analytical data from a global komatiite database are also shown (Barnes and Fiorentini 2012)

\section{Volcanology}

Several authors have emphasized the role of the eruption environment in the formation of Ni-Cu sulfide mineralization (e.g., Lesher and Keays 2002; Fiorentini et al. 2010, 2012; Barnes and Fiorentini 2008, 2012). Two main types of komatiite-related Ni$\mathrm{Cu}$ sulfide mineralization can be distinguished: (1) massive sulfide at the base of olivine-rich mesocumulate and orthocumulate zones and (2) disseminated sulfide in olivine-rich adcumulates. In both types, the $\mathrm{Ni}-\mathrm{Cu}$ sulfide mineralization occurs in close association with high-Mg olivine-rich cumulate zones. In komatiitic lava flows, olivine-rich cumulates are interpreted to represent a channelized lava conduit, where relatively unevolved, hot, and turbulently flowing lava is particularly effective in eroding the substrate, assimilating external sulfur, and precipitating sulfides in flow dynamic traps, thereby facilitating ore formation (e.g., Arndt et al. 2008; Barnes and Fiorentini 2012). In addition, komatiite sequences with the thickest cumulate package are favored for the formation of $\mathrm{Ni}$ sulfide ores as they may reflect a particularly high magma influx, probably resulting from the presence of craton-scale, deep lithospheric structures (Barnes and Fiorentini 2012).

The komatiite samples from the Vedlozero-Segozero and Tikshozero greenstone belts have similar $\mathrm{MgO}$ contents to those of the komatiites in eastern Finland, but they seem to be less magnesian than most mineralized komatiite fields elsewhere (e.g., Abitibi and Kalgoorlie) (Maier et al. 2013). The lower $\mathrm{MgO}$ content could result from a lower degree of mantle melting or a relatively advanced fractionation. Given the good overlap in the $\mathrm{MgO}$ contents between the komatiites in the Vedlozero-Segozero and Tikshozero greenstone belts, and those in eastern Finland, this interpretation may also apply to the komatiites in the current study, though olivine compositional data are not available due to the high degree of alteration.

In the Vedlozero-Segozero and Tikshozero greenstone belts, another potential explanation for the paucity of $\mathrm{Ni}-\mathrm{Cu}$ mineralization is the lack of olivine-rich cumulate units and the dominance of sheet flows, including spinifex-textured komatiites, breccia-textured komatiites, and pillow basalts. Only small serpentinite bodies that may represent lava channels occur in the Sovdozero, Koikary, and Palaselga areas. This is a significant difference compared with the komatiites in the Kalgoorlie area, which contain abundant thick (up to km scale) olivine-rich adcumulates (Fiorentini et al. 2004; Barnes and Fiorentini 2012). The scarcity of olivine-rich cumulates suggests a low magma flux rate, representing relatively unfavorable conditions to form large and extensive channelized lava tubes, which can efficiently erode their substrate and form $\mathrm{Ni}-\mathrm{Cu}$ sulfide mineralization. 
The age of the Vedlozero-Segozero greenstone belt is estimated to be ca. $2.92 \mathrm{Ga}$ (Svetov et al. 2001), i.e., similar to the ages of $2916 \pm 117$ and $2892 \pm 130$ Ma obtained for the komatiites in the Sumozero-Kenozero greenstone belt using the Sm-Nd and $\mathrm{Pb}-\mathrm{Pb}$ methods, respectively (Puchtel et al. 1999). On the other hand, these ages are slightly older than the age of ca. $2.8 \mathrm{Ga}$ determined for the Kostomuksha greenstone belt (Puchtel et al. 1998, 2005), the age of 2.82 Ga reported for the TKS greenstone belts in eastern Finland (Huhma et al. 2012), and the age of $2.8 \mathrm{Ga}$ for the Tikshozero greenstone belt. These multiple generations of komatiitic magmatism in the Fennoscandian Shield are clearly older than the global Neoarchean peak in mantle plume magmatism and $\mathrm{Ni}-\mathrm{Cu}$ sulfide mineralization at around 2.7 Ga (Arndt et al. 2008 and references therein). For reasons presently not well understood, it appears that the slightly older magma influx has less potential to form major Ni sulfide ore deposits (cf. Weihed et al. 2005; Hanski 2015). However, as the available database is relatively limited, it is difficult to assess the Ni sulfide prospectivity of these belts accurately. Future exploration work should focus on the identification of relatively prospective lava channel-facies rocks (i.e., olivine mesocumulate and adcumulates) in Archean greenstone belts.

\section{Conclusions}

Komatiites in the two studied greenstone belts in Russian Karelia show considerable similarities to those in the neighboring Archean terrane in Finland, though some of the Russian komatiites, namely those in the Vedlozero-Segozero greenstone belt, seem to be around $100 \mathrm{Ma}$ older than the Finnish komatiites. All studied Russian lavas are relatively evolved (mostly <25 wt\% $\mathrm{MgO}$ ), and their PGE contents are within the range of other unmineralized komatiites globally. The palladium-group PGE behave incompatibly, whereas the IPGEs show positive correlations with $\mathrm{Cr}$, from which we infer that they are dominantly controlled by chromite and possibly IPGE-rich phases. Considerable scatter in the Pd abundances and depletion in $\mathrm{Cu}$ and Au suggest that these elements were mobile during metamorphism and alteration. The absence of sulfide-rich sedimentary rocks in the two studied greenstone belts, the lack of PGE-enriched or depleted samples, the relatively differentiated magma composition compared with sulfide-mineralized komatiites globally, and the paucity of unevolved olivine adcumulates suggest a relatively low prospectivity for $\mathrm{Ni}$ sulfide mineralization, though localized crustal contamination and sulfide saturation seem to have occurred. However, as the available database is relatively limited, the Ni sulfide prospectivity of the studied belts remains incompletely understood, and future exploration work should focus on the identification of more prospective lava channelfacies rocks.
Acknowledgments Open access funding provided by University of Oulu including Oulu University Hospital. This study was supported by K.H. Renlund Foundation grants to FF. Guo and S.-H. Yang, a state project grant (No. AAAA-A18-118020290085-4) to S. Svetov and Z. Rybnikova, Academy of Finland grants $(276614,281859)$ to S.H. Yang and E. Hanski, and a scholarship from the Finnish graduate school of geology to FF. Guo. We thank M. Gogolev from the Institute of Geology KRC RAS for the assistance in the field work.

Open Access This article is distributed under the terms of the Creative Commons Attribution 4.0 International License (http:// creativecommons.org/licenses/by/4.0/), which permits unrestricted use, distribution, and reproduction in any medium, provided you give appropriate credit to the original author(s) and the source, provide a link to the Creative Commons license, and indicate if changes were made.

\section{References}

Arestova NA, Chekulaev VP, Matveeva LV, Kucherovskii GA, Lepekhina EN, Sergeev SA (2012) New age data on the Archean rocks of the Vodlozero domain, Baltic Shield, and their significance for geodynamic reconstructions. Dokl Earth Sci 442:1-8

Arestova NA, Chekulaev VP, Lobach-Zhuchenko SB, Kucherovskii GA (2015) Formation of the Archean crust of the ancient Vodlozero domain (Baltic Shield). Stratigr Geol Correl 23:119-130

Arndt NT, Lesher CM, Barnes SJ (eds) (2008) Komatiite. Cambridge University Press, Cambridge

Ballhaus C, Sylvester P (2000) Noble metal enrichment processes in the Merensky reef, Bushveld complex. J Petrol 41:545-561

Barnes SJ, Fiorentini ML (2008) Iridium, ruthenium and rhodium in komatiites: evidence for iridium alloy saturation. Chem Geol 257: 44-58

Barnes SJ, Fiorentini ML (2012) Komatiite magmas and sulfide nickel deposits: a comparison of variably endowed Archean terranes. Econ Geol 107:755-780

Barnes SJ, Fiorentini ML, Duuring P, Grguric BA, Perring CS (2011) The perseverance and Mount Keith Ni deposits of the Agnew-Wiluna Belt, Yilgarn craton, Western Australia. In: Li C, Ripley E (eds) Magmatic Ni-cu and PGE deposits: geology, geochemistry, and genesis. Rev Econ Geol 17:51-88

Bibikova EV, Krylov IN (1983) Isotopic age of acid volcanics from Karelia. Dokl Akad Nauk SSSR 268:1231-1235

Bibikova EV, Samsonov AV, Shchipansky AA, Bogina MM, Gracheva TV, Makarov A (2003) The Hisovaara structure in the Tikshozero greenstone belt as a Late Archaean accreted island arc: isotopic geochronological and petrological evidence. Petrol 11:261-290

Brenan JM, McDonough WF, Daplé C (2003) Experimental constrains on the partitioning of rhenium and some platinum-group elements between olivine and silicate melt. Earth Planet Sci Lett 212:135-150

Brenan JM, McDonough WF, Ash R (2005) An experimental study of the solubility and partitioning of iridium, osmium and gold between olivine and silicate melt. Earth Planet Sci Lett 237:855-87

Brownscombe W, Ihlendeld C, Coppard J, Hartshorne C, Klatt S, Siikaluoma JK, Herrington RJ (2015) The Sakatti Cu-Ni-PGE sulfide deposit in northern Finland. In: Maier WD, Lahtinen R, O’Brien H (eds) Mineral deposits of Finland. Elsevier, Amsterdam, pp 211-252

Capobianco CJ, Drake MJ (1990) Partitioning of ruthenium, rhodium and palladium between spinel and silicate melt and implications for platinum group element fractionation trends. Geochim Cosmochim Acta 54:869-874

Fiorentini ML, Stone WE, Beresford SW, Barley ME (2004) Platinumgroup element alloy inclusions in chromites from Archaean mafic- 
ultramafic units: evidence from the Abitibi and the Agnew-Wiluna greenstone belts. Mineral Petrol 82:341-355

Fiorentini ML, Barnes SJ, Lesher CM, Heggie G, Keays RR, Burnham OM (2010) Platinum-group element geochemistry of mineralized and nonmineralized komatiites and basalts. Econ Geol 105:795-823

Fiorentini ML, Beresford SW, Barley ME, Duuring P, Bekker A, Rosengren N, Cas R, Hronsky J (2012) District to camp controls on the genesis of komatiite-hosted nickel sulfide deposits, AgnewWiluna greenstone belt, Western Australia: insights from the multiple sulfur isotopes. Econ Geol 107:781-796

Fleet ME, Tronnes RG, Stone WE (1991) Partitioning of platinum group elements in the Fe-O-S system to $11 \mathrm{GPa}$ and their fractionation in the mantle and meteorites. J Geophys Res 96:21949-21958

Fleet ME, Crocket JH, Liu M, Stone WE (1999) Laboratory partitioning of platinum group elements (PGE) and gold with application of magmatic sulfide-PGE deposits. Lithos 47:127-142

Godel B, Barnes SJ, Maier W (2007) Platinum-group elements in sulphide minerals, Platinum-group minerals and whole-rocks of the Merensky Reef (Bushveld Complex, South Africa): implications for the formation of the reef. J Petrol 48:1569-1604

Godel B, Barnes SJ, (2008). Image analysis and composition of platinumgroup minerals in the J-M reef, Stillwater complex. Econ Geol 103: 637-651

Hanski E (1980) Komatiitic and tholeiitic metavolcanics of the Siivikkovaara area in the Archean Kuhmo greenstone belt, eastern Finland. Bull Geol Soc Finl 52:67-100

Hanski E (2015) Synthesis of the geological evolution and metallogeny of Finland. In: Maier WD, Lahtinen R, O'Brien H (eds) Mineral deposits of Finland. Elsevier, Amsterdam, pp 51-88

Huhma H, Mänttäri I, Peltonen P, Kontinen A, Halkoaho T, Hanski E, Hokkanen T, Hölttä P, Juopperi H, Konnunaho J, Lahaye Y, Luukkonen E, Pietikäinen K, Pulkkinen A, Sorjonen-Ward P, Vaasjoki M, Whitehouse M (2012) The age of the Archaean greenstone belts in Finland. In: Hölttä P (eds) The Archean of the Karelia Province in Finland. Geol Surv Finland, Spec Paper 54:74-175

Hölttä P, Heilimo E, Huhma H, Kontinen A, Mertanen S, Mikkola P, Paavola J, Peltonen P, Semprich J, Slabunov A, Sorjonen-Ward P (2012) The Archaean of the Karelia Province in Finland. In: Hölttä P (eds), The Archean of the Karelia Province in Finland. Geol Surv Finland, Spec Paper 54:21-73

Jahn BM, Auvray B, Capdevila R, Cornichet J, Vidal F, Hameurt J (1980) Trace element geochemistry and petrogenesis of Finnish greenstone belts. J Petrol 21:201-244

Keays RR, Lightfoot PC (2010) Crustal sulfur is required to form magmatic $\mathrm{Ni}-\mathrm{Cu}$ sulphide deposits: evidence from chalcophile element signatures of Siberian and Deccan Trap basalts. Mineral Deposita 45:241-257

Konnunaho JP, Hanski EJ, Bekker A, Halkoaho TAA, Hiebert R, Wing BA, Karinen T (2013) The Archean komatiite-hosted, PGE-bearing $\mathrm{Ni}-\mathrm{Cu}$ sulfide deposit at Vaara, eastern Finland: evidence for assimilation of external sulfur and post-depositional desulfurization. Mineral Deposita 48:967-989

Konnunaho J, Halkoaho T, Hanski E, Törmänen T (2015) Komatiitehosted Ni-Cu-PGE deposits in Finland. In: Maier W, O'Brien H, Lahtinen R (eds) Mineral deposits of Finland. Elsevier, Amsterdam, pp 93-127

Kozhevnikov VN (1992) Geology and geochemistry of the Archaean North Karelian greenstone structures. Karelian Research Center, Russian Academy of Sciences, Petrozavodsk (in Russian)

Kozhevnikov VN (2000) Archean greenstone belts of the Karelian craton as accretionary orogens. Karelian Research Centre, Russian Academy of Sciences, Petrozavodsk (in Russian)

Kozhevnikov VN, Berezhnaya NG, Presnyakov SL, Lepekhina EN, Antonov AV, Sergeev SA (2006) Geochronology (SHRIMR-II) of zircon from Archean lithotectonic associations in the greenstone belts of the Karelia craton: implications for stratigraphic and geodynamic reconstructions. Stratigr Geol Correl 14:240-259

Kuleshevich LV, Gor'kovets VY (2008) Mineralogy of the Precambrian Southern Kostomuksha gold prospect in Karelia. Geol Ore Deposits 7:599-608

Lahaye Y, Barnes SJ, Frick LR, Lambert DD (2001) Re-Os isotopic study of komatiitic volcanism and magmatic sulfide formation in the southern Abitibi greenstone belt, Ontario, Canada. Can Mineral 39:473-490

Lesher CM, Barnes SJ (2009) Komatiite-associated Ni-Cu-PGE deposits. In: Li C, Ripley EM (eds) New developments in magmatic Ni-Cu and PGE deposits. Geological Publishing House, Beijing, pp 27120

Lesher CM, Keays RR (2002) Komatiite-associated Ni-Cu-PGE deposits: geology, mineralogy, geochemistry and genesis. In: Cabri LJ (eds) The geology, geochemistry, mineralogy and beneficiation of platinum-group elements Can Inst Mining Metall Petrol, Spec Vol 54: 579-617

Lightfoot PC, Hawkesworth CJ (1997) Flood basalts and magmatic Ni, $\mathrm{Cu}$, and PGE sulphide mineralization: comparative geochemistry of the Noril'sk Siberian traps and west Greenland sequences. In: Mahoney J, Coffin M (eds) Large igneous provinces: Continental, oceanic and planetary flood basalt volcanism. Am Geophys Union Monogr 100:357-380

Locmelis M, Fiorentini ML, Barnes SJ, Pearson NJ (2013) Ruthenium variation in chromite from komatiites and komatiitic basalts - a potential mineralogical indicator for nickel sulfide mineralization. Econ Geol 108:355-364

Locmelis M, Fiorentini ML, Barnes SJ, Hanski E, Kobussen AF (2018) Ruthenium in chromite as an indicator for the magmatic sulfide ore potential of mafic-ultramafic systems. Ore Geol Rev 97:152-170

Maier WD, Roelofse F, Barnes SJ (2003) The concentration of the platinum-group elements in South African komatiites: implications for mantle sources, melting regime and PGE fractionation during crystallization. J Petrol 44:1787-1804

Maier WD, Peltonen P, Halkoaho T, Hanski E (2013) Geochemistry of komatiites from the Tipasjärvi, Kuhmo, Suomussalmi, Ilomantsi and Tulppio greenstone belts, Finland: implications for tectonic setting and Ni sulphide prospectivity. Precambrian Res 228:63-84

Maier WD, Rasmussen B, Fletcher I, Godel B, Barnes SJ, Fisher L, Yang S, Huhma H, Lahaye Y (2015) Petrogenesis of the 2.77 Ga Monts de Cristal complex, Gabon: evidence for direct precipitation of Ptarsenides from basaltic magma. J Petrol 56:1285-1308

Makkonen HV, Halkoaho T, Konnunaho J, Rasilainen K, Kontinen A, Eilu P (2017) Ni-(Cu-PGE) deposits in Finland-geology and exploration potential. Ore Geol Rev 90:667-696

McDonald I, Viljoen KS (2006) Platinum-group element geochemistry of mantle eclogites: a reconnaissance study of xenoliths from the Orapa kimberlite, Botswana. Appl Earth Sci Trans Inst Mining Metall B 115:81-93

McDonough WF, Sun SS (1995) The composition of the earth. Chem Geol 120:223-253

Melezhik VA, Medvedev PV, Svetov SA (2012) The Onega basin. In: Melezhik V, Prave AR, Fallick AE, Kump LR, Strauss H, Lepland A, Hanski EJ (eds) Reading the archive of Earth's oxygenation. Volume 1: The Palaeoproterozoic of Fennoscandia as context for the Fennoscandian Arctic Russia - Drilling Early Earth Project. Springer-Verlag, Berlin, Heidelberg, pp 387-490

Mudd GM, Jowitt S (2014) A detailed assessment of global nickel resource trends and endowments. Ecol Geol 109:1813-1841

Nesbitt RW, Sun SS, Purvis AC (1979) Komatiites: geochemistry and genesis. Can Mineral 17:165-186

Pagé P, Barnes SJ, Bédard JH, Zientek ML (2012) In situ determination of $\mathrm{Os}, \mathrm{Ir}$, and $\mathrm{Ru}$ in chromites formed from komatiite, tholeiite and boninite magmas: implications for chromite control of Os, Ir and 
Ru during partial melting and crystal fractionation. Chem Geol 302303:3-15

Papunen H, Halkoaho T, Luukkonen E (2009) Archaean evolution of the Tipasjärvi-Kuhmo-Suomussalmi Greenstone Complex, Finland. Geol Surv Finl Bull 403

Park J-W, Kamenetsky V, Campbell I, Park G, Hanski E, Pushkarev YE (2017) Empirical constraints on partitioning of platinum group elements and trace elements into $\mathrm{Cr}$-spinel from primitive terrestrial magmas. Geochim Cosmochim Acta 216:393-416

Puchtel IS, Humayun M (2001) Platinum group element fractionation in komatiitic basalt lava lake. Geochim Cosmochim Acta 65:29792993

Puchtel IS, Hofmann AW, Mezger K, Jochum KP, Shchipansky AA, Samsonov AV (1998) Oceanic plateau model for continental crustal growth in the Archaean: a case study from the Kostomuksha greenstone belt, NW Baltic Shield. Earth Planet Sci Lett 155:57-74

Puchtel IS, Hofmann AW, Amelin YV, Garbe-Schonberg C-D, Samsonov AV, Shchipansky AA (1999) Combined mantle plume-island arc model for the formation of the 2.9 Ga Sumozero-Kenozero greenstone belt SE Baltic Shield: isotope and trace element constraints. Geochim Cosmochim Acta 63:3579-3595

Puchtel IS, Brügmann GE, Hofmann AW (2001) ${ }^{187}$ Os-enriched domain in an Archaean mantle plume: evidence from $2.8 \mathrm{Ga}$ komatiites of the Kostomuksha greenstone belt, NW Baltic Shield. Earth Planet Sci Lett 186:513-526

Puchtel IS, Humayun M, Campbell AJ, Sproule RA, Lesher CM (2004) Platinum group element geochemistry of komatiites from the Alexo and Pyke Hill areas, Ontario. Geochim Cosmochim Acta 68:13611383

Puchtel IS, Humayun M, Walker RJ (2007) Os-Pb-Nd isotope and highly siderophile and lithophile trace element systematics of komatiitic rocks from the Volotsk suite, SE Baltic Shield. Precambrian Res 158:119-137

Righter K, Campbell AJ, Humayun M, Hervig RL (2004) Partitioning of $\mathrm{Ru}, \mathrm{Rh}, \mathrm{Pd}$, Re, Ir, and Au between Cr-bearing spinel, olivine, pyroxene and silicate melts. Geochim Cosmochim Acta 68:867-880

Rudnick RL, Gao S (2003) Composition of the continental crust. In: Rudnick RL (Ed), The Crust. Elsevier, Amsterdam pp 1-70

Samsonov AB, Bibikova EV, Puchtel IS (1996) Isotopic and geochemical differences between acid volcanic rocks from greenstone belts of Karelia and their geotectonic significance. In: Correlation between geologic complexes of Fennoscandia. Mineral Publ., St. Petersburg, pp 74-75 (in Russian) $74 \mathrm{p}$

Savard D, Barnes SJ, Meisel T (2010) Comparison between nickel-sulfur fire assay Te co-precipitation and isotope dilution with high-pressure asher acid digestion for the determination of platinum-group elements, rhenium and gold. Geostand Geoanal Res 34:281-291

Shchipansky AA, Samsonov AV, Bibikova EV, Babarina II, Konilov AN, Krylov KA, Slabunov AI, Bogina MM (2004) 2.8 Ga boninite- hosting partial suprasubduction zone ophiolite sequences from the North Karelian Greenstone Belt, NE Baltic Shield, Russia. In: Kusky TM (ed) Precambrian ophiolites and related rocks. Elsevier, Amsterdam, pp 425-486

Slabunov AI, Lobach-Zhuchenko SB, Bibikova EV, Balagansky VV, Sorjonen-Ward P, Volodichev OI, Shchipansky AA, Svetov SA, Chekulaev VP, Arestova NA, Stepanov VS (2006) The archean of the baltic shield: Geology, geochronology, and geodynamic settings. Geotect 40:409-433

Sorjonen-Ward P, Luukkonen EJ (2005) Archean rocks. In: Lehtinen M, Nurmi P, Rämö T (eds) Precambrian geology of Finland - key to the evolution of the Fennoscandian Shield. Elsevier, Amsterdam, pp 9 93

Stone WE, Crocket JH (2003) Platinum-group element contents of chromites from mafic-ultramafic layered flows, Abitibi greenstone belt, Ontario: implications for geochemical fractionation and mineral exploration. Mineral Petrol 78:139-147

Stone WE, Crocket JH, Fleet ME (1990) Partitioning of palladium, iridium, platinum and gold between sulfide liquid and basalt melt at $1200^{\circ} \mathrm{C}$. Geochim Cosmochim Acta 54:2341-2344

Svetov SA (2005) Magmatic systems in the ocean-continent transition zone in the Archean of the eastern Fennoscandian Shield. Karelian Research Center, Russian Academy of Sciences, Petrozavodsk (in Russian)

Svetov SA, Smolkin VF (2003) Model P-T conditions of high-magnesia magma generation in the Precambrian of the Fennoscandian Shield. Geochem Int 41:799-812

Svetov SA, Svetova AI, Huhma H (2001) Geochemistry of the komatiitetholeiite rock association in the Vedlozero-Segozero Archean greenstone belt, Central Karelia. Geochem Int 39:24-38

Svetov SA, Kudryashov NM, Ronkin YL, Huhma H, Svetova AI, Nazarova TN (2006) Mesoarchean island-arc association in the Central Karelian terrane, Fennoscandian Shield: new geochronological data. Dokl Earth Sci 406:103-106

Svetov SA, Svetova AI, Nazarova TN (2010) Vedlozero-Segozero greenstone belt, Central Karelia: new age data and interpretation of the results. Geol Useful Miner Karelia 13:5-12 (in Russian)

Weihed P, Arndt N, Billström K, Duchesne JC, Eilu P, Matinsson O, Papunen H, Lahtinen R (2005) Precambrian geodynamics and ore formation: the Fennoscandian Shield. Ore Geol Rev 27:273-322

Publisher's note Springer Nature remains neutral with regard to jurisdictional claims in published maps and institutional affiliations. 